VATT Working Papers 137

Resource and Environmental Policies for the Mining Industry: What Should Governments Do About the Increasing Social and Environmental Risks?

Anni Huhtala

Olli Ropponen 


\section{VATT WORKING PAPERS}

\section{7}

Resource and Environmental Policies for the Mining Industry: What Should Governments Do About the Increasing Social and Environmental Risks?

Anni Huhtala Olli Ropponen 
Anni Huhtala, VATT Institute for Economic Research, anni.huhtala@ vatt.fi Olli Ropponen, VATT Institute for Economic Research, olli.ropponen@vatt.fi

ISBN 978-952-274-265-0 (PDF)

ISSN 1798-0291 (PDF)

URN:ISBN:978-952-274-265-0

Valtion taloudellinen tutkimuskeskus

VATT Institute for Economic Research

Arkadiankatu 7, 00100 Helsinki, Finland

Helsinki, December 2020 


\title{
Resource and Environmental Policies for the Mining Industry: \\ What Should Governments Do About the Increasing Social and Environmental Risks?*
}

Anni Huhtala and Olli Ropponen

VATT Institute for Economic Research

December 2020

\begin{abstract}
Growing demand for materials required in the construction of renewable technologies and zeroemission infrastructure may signal significant changes for the minerals and metals market. These in turn might exacerbate the social and environmental risks associated with the mining industry. We explore the impacts of commodity price volatility, the adoption of new technology and environmental risks on the long-term sustainability of a stylized mining firm and examine the implications for government policy intervention. We first analyze whether a mine should remain open or be closed when premature closing is costly due to land rehabilitation and reclamation resulting from an environmental accident. We then go on to investigate alternative resource policy instruments for by which the government may extract resource rents, examples being an ad valorem tax on output, a mining industry-specific corporate tax rate and a royalty on the amount of ore removed. Furthermore, we evaluate the potential of a number of means to correct for environmental externalities and compensate for damages that a mine causes during its lifetime, specifically a Pigou tax on effluents, fines on environmental accidents, mandatory up-front payments to an environmental liability fund and a surety bond to cover closure and reclamation costs.
\end{abstract}

Q31 Q38 Q52

Keywords: royalty, fines, liability payment, surety bond, Pigou tax, ad valorem tax, excess corporate $\operatorname{tax}$

* We would like to thank the participants of the $41^{\text {st }}$ Annual Meeting of the Finnish Economic Association, NAERE 2018 workshop, EAERE 2020 conference, the seminars of VATT Institute for Economic Research and the Finnish Ministry of Finance for constructive comments. We are grateful for valuable feedback to Santtu Karhinen, Essi Eerola, Ilkka Harju, Lassi Ahlvik, Seppo Kari, Pauli Lappi, Marita Laukkanen, Kimmo Ollikka, Anna Sahari, Seppo Orjasniemi and Anna-Maija Juuso. We thank Jan Weckström and Jaakko Leppänen of the University of Helsinki, Joni Kivipelto of the Kainuu Centre for Economic Development, Transport and the Environment, and Bertel Vehviläinen, Noora Veijalainen and Sari Kauppi of the Finnish Environment Institute for advice and data on environmental impacts. We thank Richard Foley for correcting our English. The usual caveat applies. 


\section{Introduction}

Growing demand for materials required in the construction of renewable technologies and zeroemission infrastructure may lead to significant changes in the minerals and metals market. A major concern is that extraction of key materials may exacerbate the social and environmental risks associated with the mining industry. This is pronounced in the case of government regulation of mining companies, which often operate in remote, sparsely populated areas where policy makers are keen on spurring development and employment opportunities. This is true in both developing and highly developed countries. (Prior et al 2012, Chakarvarty 2018, Addison and Roe 2018)

In the literature, the contribution of the extractive industries to economic growth has been investigated in cross-country comparisons (Cust and Poelhekke 2015). The "resource curse" hypothesis introduced by Sachs and Warner (2001) intensified empirical research on the welfare impacts of nonrenewable resources, and the focus shifted to within-country effects on local or regional development. The evidence to date comprises findings both in favor of and against the resource curse hypothesis, and scientific debate on natural resource wealth continues (e.g., van der Ploeg 2011).

In the international policy arena, natural resource management and environmental policy have frequently been discussed in terms of sustainable or 'green' growth and, most recently, 'the circular economy' (e.g., OECD 2015, COM 2020). Yet, there seems to be limited understanding - or political acceptance - of the fact that when market prices do not reflect the social costs of resource use and environmental degradation, the market mechanism fails and government intervention becomes necessary. Where this is the case, governments considering policies to support local employment and livelihoods by promoting mining operations should provide proper incentives for extractive industries to act in a socially responsible manner worldwide.

This paper explores the long-term sustainability of a stylized mining firm and implications for government policy intervention in that context. Our analysis is motivated by the concern that regulation is not fully integrated where the expected growth of the mining sector is concerned. There are special features of the sector that distinguish it from other industries. The impacts of commodity price volatility, the adoption of new technologies and environmental risks affecting the operating environment and profitability of mines must be considered.

First, price fluctuations are an inherent feature of the markets for nonrenewable natural resources where mined metals, minerals and mineral fuels are traded. Unexpected changes in business cycles and expectations about future shortfalls of supply and inventories are typical reasons for the price 
volatility. Since minerals industries are capital intensive, adjusting extractive capacity and production to prevailing prices may be inelastic, and changes in demand will be resolved through changes in price rather than changes in quantity. (Krautkraemer 1998, Baumeister and Kilian 2016, Jacks and Stuermer 2020)

Second, invention of substitutes and technological progress play a crucial role in nonrenewable resource extraction, and deployment of new technology may increase uncertainty about the quantities that will be extracted. As adoption of new technology involves learning by doing - which takes time - drastic price fluctuations heighten risks in mining operations and affect the profitability of a mining firm. Risks in production often materialize when prices collapse. An increasing concern from a social point of view is the unexpected environmental impacts that new technology may entail. Moreover, environmental monitoring may be inadequate and lead to catastrophic environmental degradation. At worst, immense human losses and environmental damages are caused by accidents such as collapsed dams and tailings spills. ${ }^{1}$

We elaborate a profit-maximization problem of a prototype mine affected by risks and uncertainties related to prices, technology and environmental impacts. Our modelling builds upon previous literature in which a general theory of the mining firm has been developed (Hotelling 1931, Kemp and Long 1980). Since the work of Brennan and Schwartz (1985), stochastic dynamic programming and numerical simulations have been used for solving complex decision problems, for example, determining the optimal time to develop and abandon a mine (see, e.g., Mason 2001, 2012; Insley 2017). Specifically, the theory of real options in the timing of investments was emphasized by Dixit and Pindyck (1994) and in fact it has been shown that real options are exercised in practice in timing decisions in extractive industries (see, e.g., Kellogg 2014). Here, we adopt a broader scope than optimal timing problems; our modelling must tackle not only the uncertainty of prices but also technology and environmental risks as they affect the profitability of a mine during its lifespan from opening to closure. Specifically, we model price volatility and distinguish in our simulations that both jumps and regime shifts occur regularly in metal prices, as has been observed in the past. Furthermore, adoption of new technology is learning by doing, and learning prolongs the time required for reaching a mine's planned, stable production level. We have also designed the model to incorporate random variation in discharges of effluents into the environment and probabilities of environmental accidents, and investigate the impact of these considerations on a firm's and government's optimal decisions.

\footnotetext{
${ }^{1}$ As evidenced, for example, by the collapse of the Brumadinho dam in Brazil in 2019. The fatal incident is considered the worst environmental disaster in the country's history. BBC News January 25, 2020.
} 
Given the uncertainties described above, we first ask what a regulator should do if a large-scale environmental accident has occurred in a mine. A government must obtain knowledge on whether to close the mine permanently because of financial or environmental concerns. This is a real-world problem for regulators of mining companies, as closing a mine is costly and the related environmental remediation must ultimately be taken care of by the government. Second, in a further contribution to the literature, we consider socially optimal pricing of the nonrenewable resource and internalization of externalities generated in mining. The features that justify government intervention in regulating mining are extraction of a nonrenewable resource (scarcity), stochastic environmental externalities (flows of pollution) and a sudden environmental disaster (terminal damage value of a polluting mine). In simulations of a mining firm operating under uncertainty during its lifetime, we analyze government intervention with policy instruments adequate for pursuing the goal of sustainable mining.

Optimal taxation of a firm exploiting nonrenewable natural resources has been discussed extensively in the literature (e.g., Lund 2009, Gaudet and Lasserre 2015, Boadway and Keen 2015). Similarly, there are several analytical papers that have investigated optimal abatement of polluting effluents, clean-up of polluted mining sites and environmental regulation (e.g., White 2015, Yang and Davis 2018, Lappi 2020). Moreover, enforcement policies such as fines and sanctions have been considered as means to prevent and compensate for environmental hazards in case of violation (e.g., Arguedas 2005). In the end, a fully financed strategy for mine closure in an environmentally sound way and post-closure monitoring are essential aspects of enforcement in the regulation of mines. To ensure regulatory compliance, a government may consider intervention to prevent the mining firm from going bankrupt and, ultimately, to avoid the firm abandoning the mine without assuming responsibility for cleanup (for empirical analyses, see, e.g., Muehlenbachs 2015; Boomhower 2019).

As our contribution to the previous analyses, we extend the modelling by first analyzing whether the mine should remain open or closed when (premature) closing is costly due to events such as an environmental accident requiring large-scale land rehabilitation and reclamation. Obviously, we cannot solve the dynamic optimization problem analytically when considering the price, technology and environmental uncertainties simultaneously. The dynamic problem is solved by simulations for a prototype mine that reflects stylized features of a multi-metal mine. Thereafter, we carry out simulations with alternative policy instruments such as taxes, liability payments and fines for internalizing externalities that generate social costs. We report the simulation results for the net present value of the mine as well as government revenues from combinations of alternative resource 
and environmental policy instruments over the lifecycle of the mine. This is important for policy implementation and the design of taxation and liability payments.

The paper is organized as follows. The next section provides background on the mining industry, the operating environment of a typical mining firm and regulation. In section 3, stylized features of price volatility, learning by doing and environmental risks are empirically motivated, estimated and calibrated for the modelling to follow. In section 4, the mining firm's extraction problem is explicitly presented for simulations under uncertainty and resource and environmental policy. Parameterization of the simulation model and the results of the benchmark simulations are reported in section 5. Section 6 discusses simulations with policy instruments. Section 7 concludes.

\section{The mining industry: market and policy uncertainties and regulation}

Rising production of metals and dramatically increasing and then declining prices are typically coincident with phases of economic growth and business cycles. During the 21 st century, the increase in demand in developing countries, most prominently in China and India, has had a considerable impact on prices. Currently, the emerging trends with policy and potential market impacts are global warming, rising energy costs and technological development in energy and other production. (Papp et al. 2008; Jones 2016)

Impacts of global energy and climate policies are spilling over from the energy sector to other industries. Increasing consumption of renewable energy and a switch from fossil fuels to renewable inputs in the generation of electricity, which requires storage capacity, is shifting demand to key materials for the changing energy system. One salient question is whether the key base metals, including copper, silver, aluminum, nickel and zinc, will benefit from a low-carbon energy shift or will constrain the growth of clean technology in the course of the century. (World Bank 2017)

Moreover, increasing demand for key materials may exacerbate the social and environmental risks associated with the mining industry. In other words, there is a trade-off between carbon emissions and the environmental impacts of exploiting alternative energy sources. In economics, this was recognized early on by Ayres and Kneese (1969), who showed in their materials balance framework that technological-external diseconomies are not peculiar anomalies in the processes of production and consumption but rather an inherent and normal part of them. These externalities cannot be properly dealt with by considering environmental media such as air and water in isolation. Isolated and ad hoc taxes and other restrictions are not sufficient for their optimal control, as regulation of one 
pollutant induces technological change that may transform pollution to another form of waste that is not regulated.

Ultimately, environmental problems as well are related to scarcity of materials. Poorer and poorer ore quality means that extensive amounts of ore are moved in large areas of open-pit mining, leaving behind visible scars in the landscape. Moreover, with chemical reagents being used in mineral processing, environmentally harmful substances may be released into nature and waterways. Water management has become a major challenge in mining operations. Both flows of effluents into the environment and unexpected environmental accidents should be considered when planning mining operations if a mine is to avoid human losses and environmental damages.

In the following, we briefly illustrate the uncertainties related to commodity prices and technological development in the mining industry as well as risks caused by environmental damage, which may range from water and soil pollution to waste management and reclamation. Finally, we introduce policy instruments that may be used for regulating the industry.

\subsection{Price process}

In his seminal article, Harold Hotelling (1931) showed analytically that nonrenewable resource prices rise because of increasing scarcity. Obviously, the Hotelling model did not incorporate the possibility of a variety of uncertain events, such as the invention of substitutes or new discoveries that can cause shifts in the time path for resource rents, or in situ values. In general, price fluctuations are caused by considerations such as shocks to production and technology (supply) and unexpected changes in business cycles and expectations about future shortfalls of supply and inventories (demand). In practice, commodity prices are subject to rapid and unexpected changes, and irregular price volatility has been seen in the development of price indices for industrial commodities in recent decades. Different metals are often mined simultaneously, which may contribute to co-movement of certain commodity prices. In addition, prices of the precious metals (gold, platinum, and silver) have been more volatile in comparison to those of other metals. (See, e.g., Chevallier and Ielpo 2014, World Bank 2020.)

Rising production and dramatically increasing and declining prices have been seen as coinciding with economic growth. This notion was introduced by Sachs and Warner (2001) as a 'resource curse' hypothesis. However, Ferraro and Peretto (2017) have highlighted that commodity prices may affect growth only in the short run. Whether exogenous movements in commodity prices accelerate or decelerate short-run growth depends on the overall substitutability between labor and commodity use 
in materials production. Hence, it is possible to observe co-movement of manufacturing production and metal prices for a short transition period. As a concrete example, production of stainless steel accounts for two-thirds of primary nickel use worldwide, with more than one-half of the steel going into the construction, food processing and transportation sectors. Other events with potential price impacts are consolidation of the steel industry, global warming and carbon sequestration, and rising energy costs. (Papp et al. 2008). In the mining industry, peaks and downturns in metal prices affect financial plans and profitability calculations in the short run, and investment decisions in the long run.

\subsection{Technical change, production and environmental impacts}

One of the main reasons why finite availability of nonrenewable resources has not resulted in increasing resource rents is technological progress. New technological options directly affect production opportunities in the mining industry, as in others. The demand for metals and minerals in new uses also reflects the constant technological change that spills over to extractive industries. Recently, deployment of low-carbon technologies has had the most pronounced impact on depletion of materials, raising questions as to whether critical metals will be available in sufficient quantities in the future. (Chakarvarty 2018)

The decline in discovery of new deposits in traditional mining districts has led to exploration in more challenging locations, such as east-central Africa and the subarctic. In general, unconventional lowgrade bulk tonnage deposits are increasingly becoming an attractive target for exploration and conversion of resources to production. Site-specific conditions and ore type are critical also for operating and capital costs. When a mine employs a new and relatively uncertain production technology, the uncertainty in the extracted amounts is likely to play a more important role than in it does in mines employing more conventional technologies. In the end, problems in the production process and the consequent decreases in the extraction amounts affect the profits (losses) of the mine. (Kyle 2010, Wedderburn 2010, Mudd and Jowitt 2014, USGS 2019)

Ultimately, successful development of mining operations depends on many factors related to social acceptance, investment transparency, accountability and environmental practices. There has been a change over time in the design of mining operations towards the view that economically viable mining must be socially and environmentally acceptable. However, rapid technological development, for example in the renewable energy and battery storage industries, will increase demand for materials that originate and are processed in challenging environments. In many countries, concerns related to environmental damage and worker health and safety have led to suspension of mining operations for 
failing to meet environmental standards. The problem of waste management is one of the greatest challenges for mines that do not adhere to regulations regarding proper waste disposal. In such cases, soil and water may be contaminated by hazardous substances, such as heavy metals and radioactive materials. (e.g., Warhurst and Mitchell 2000, Jenkins and Yakovleva 2006, MIT 2016, Conde 2017)

Mining companies are looking to alternative technologies for the processing of low-grade metalliferous ores. For example, heap leaching is a hydrometallurgical technique that often has lower operation costs than conventional processing techniques, and is increasingly being considered in the design of new mines and the expansion of existing operations. However, in several projects production from unconventional, low-grade resources has turned out to be challenging even if the demonstration phase has been successfully implemented. There are several well-documented examples of heap leaching facilities where poor design and mismanagement have resulted in environmental damage, particularly to the aquatic environment and downstream ecosystems. Environmental risks have materialized in the form of leaks from tailings dams, and production has been halted or slowed. (Reichardt 2008, Mudd and Jowitt 2014) For these reasons, risk assessment is increasingly used in the design of mining operations, and assessment approaches have been developed especially for the extraction of metal from mined ore by heap leaching (Guyonnet and Touze-Foltz 2014).

2.3 Alternative policy instruments discussed in the literature and implemented in practice

Resource and environmental policy should provide mining firms with incentives for sustainable use of nonrenewable resources. In the case of optimal resource policy, the theoretical argument for government intervention is that rents from non-renewable resources should be invested in renewable capital. This is what is known as Hartwick's rule for a socially optimal, or sustainable, growth policy. (Hartwick 1977) Hence, government intervention by taxing rents from nonrenewable resources is justified by a commitment to invest the tax revenues in a renewable, and thus sustainable, capital stock. In practice, it is becoming increasingly common to set up state-owned funds that receive an infusion of capital from fiscal revenues to provide for future sustainable income. (Otto 2018) How exactly tax revenues should be used to promote growth and well-being is an interesting policy question per se, but we do not elaborate on the issue here (see, e.g., van der Ploeg and Venables 2018).

Instead, we consider tax tools that could be used so that society would receive its fair share of benefits. There is an extensive literature in economics on mining that has considered the issues of resource policy and taxation (see, e.g., Daniel et al 2010, Gaudet and Lasserre 2015, Boadway and Keen 2015). In principle, the taxation of a mine can be adjusted to capture its economic rent. Nevertheless, in 
practice few nations attempt to capture all economic rent, but do use taxes, such as income tax or excess profits taxes, to appropriate some economic rent for the benefit of state. It should be emphasized that when studying taxation, the various components of a tax system should be examined. For example, comparison of royalty rates in different nations may be misleading, because other tax types may offset any differences in rates. Therefore, a variety of tax scenarios using modelling is helpful in putting forward a policy analysis for tax reform in the mining sector (Otto 2018).

In addition to resource policy, intervention through environmental regulation is needed, as natural resources extraction inevitably causes environmental damage for and imposes costs on society. During resource extraction and operation of a mine, environmental degradation is typically caused by effluents generated as by-products of the ore extracted. Pigou (1920) suggested taxes on externalities, that is, pollutants, as a policy prescription. Furthermore, legal liability for accidents and precautionary measures for remediation and reclamation should be considered if it is likely that mining operations will lead to environmental accidents during the lifetime of the mine (for liabilities, see, e.g., Shavell 2007).

There are several analytical papers that have investigated optimal abatement of polluting effluents, clean-up of polluted mining sites and the role of environmental regulation (e.g., White 2015, Yang and Davis 2018, Lappi 2020). Ultimately, a government wants to prevent a mining firm from abandoning the mine without assuming responsibility for a cleanup. Yin et al (2011) find a traditional policy instrument, ex-post fines, inefficient for the very reason that firms may declare bankruptcy and escape their liabilities. In empirical work, alternative policy intervention using financial assurance has recently been analyzed in Boomhover (2019), for example, using administrative data from oil drilling in Texas.

In sum, the relevant features that call for deployment of government intervention in regulating mining are (i) extraction of a nonrenewable resource (scarcity), (ii) stochastic environmental externality as a by-product of mining technology (flow of pollution) and (iii) environmental disaster or accumulated environmental damage (terminal value of polluting mine). Here, we consider several alternative instruments that a government has at its disposal: a royalty, an ad valorem tax, a corporate tax, Pigou taxes, fines for environmental accidents occurring during the operation of a mine, a mandatory payment to an environmental liability fund, and a financial surety to cover reclamation and environmental restoration when the ore-extracting activities have ceased. 


\section{Modelling uncertainty related to prices, production technology and environmental impacts}

In this section, we model certain features of resource markets regarding price volatility and technology uncertainty, as well as environmental risks that cause environmental damage and, in turn, may hamper extraction and production. We formalize these stochastic elements, which must be considered in a mining firm's decision making.

We elaborate a prototype mine operating in nonrenewable resource markets. The parameters underlying our simulations reflect stylized features of a multi-metal mine extracting nickel and zinc. To illustrate the challenges in learning a new mining technology, we use quantities that have been extracted in a representative mine that has adopted heap leaching technology with biological activation, or bioleaching. Metal recovery from conventional heap leaching (see, e.g., Roan and Martin 1996) and bioleaching (Halinen, 2015) is a complex process requiring various stages of minerals removal. Potential problems in production technology translate into difficulties for environmental management in the mine. The process produces both residue in the form of leached ore and chemical precipitates from the recovery plant. (Kappes 2002, Reichardt 2008, Guyonnet and Touze-Foltz 2014) Exceptionally high precipitation or other unfavorable weather conditions can lead to major leakage; depending on the magnitude of the leakage, production may be interrupted or suspended. This being the case, it is important to model and parameterize both constant flows of effluents and sudden environmental accidents. Next, we introduce the stochasticity of the variables of interest and show how our model is parameterized.

\subsection{Prices}

To take account of the volatility of commodity prices in the basic model, we calibrate the price process, $p^{t}$, for each metal, $i$, such that $\tilde{p}_{i}^{t}=p_{i}^{t}+\mu_{i}$, where $\mu_{i}$ is a random term and $t$ denotes a time period. In the following, stochasticity of the variable of interest is always denoted by a tilde.

In previous modelling, several authors have assumed that the spot price of a given exhaustible resource follows a geometric Brownian motion (GBM) with drift (for references, see Lund 2009). ${ }^{2}$ We study the profitability of a mining firm over its lifecycle where the fluctuation in mineral prices is given. We carry out the modelling of the stochastic prices by using historical data on metal prices. This is particularly useful, as we recognize metal-specific patterns for stochasticity such as jumps,

\footnotetext{
${ }^{2}$ There are certain concerns related to the assumption of GBM; see, e.g. Lund (1993), who has shown why GBM is hardly an equilibrium price process.
} 
and regime shifts that bring realism to modelling of the operating environment of the mine. We motivate and discuss these features below with an illustration of historical metal price developments.
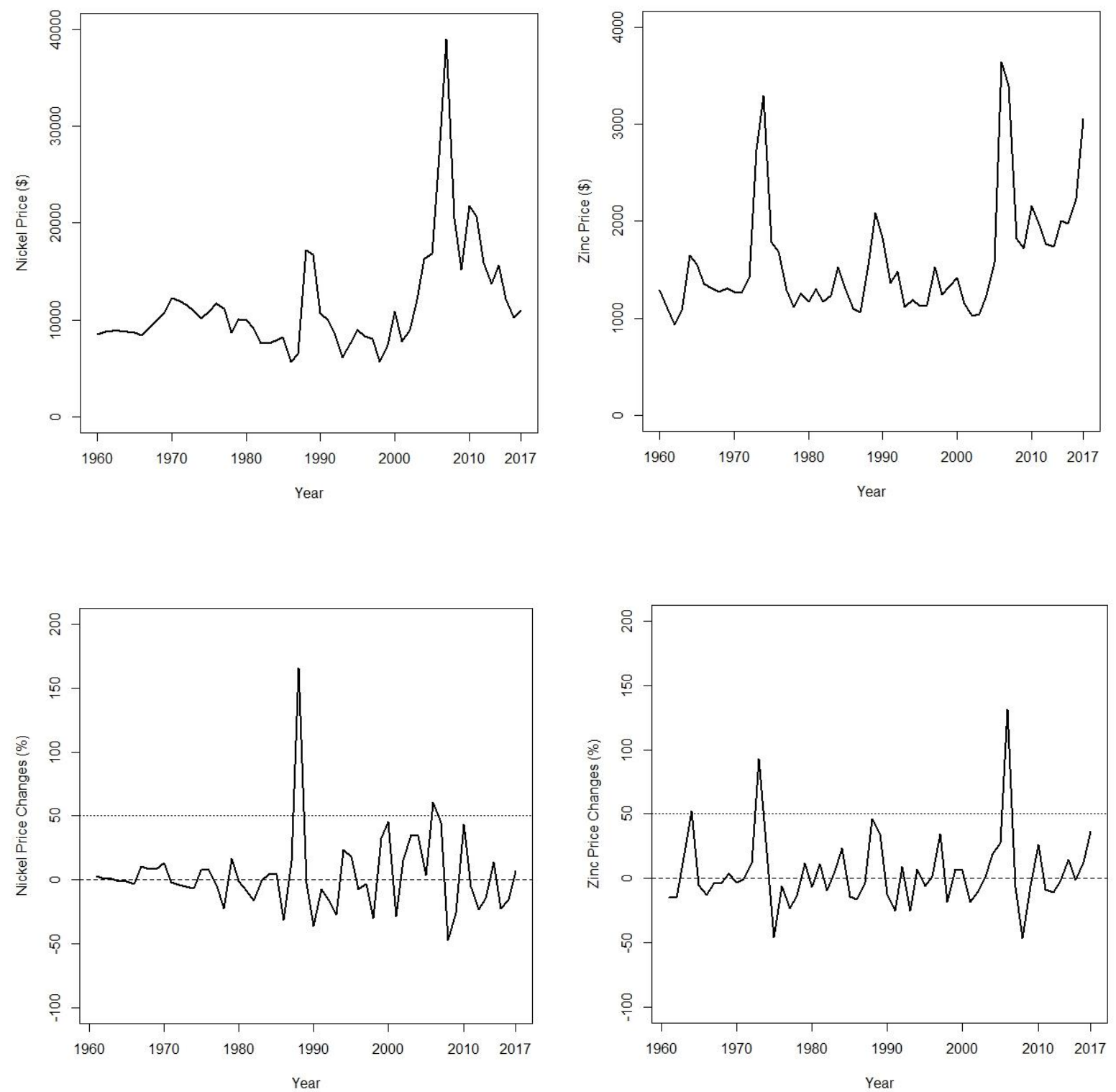

Figure 1. Evolution of prices of nickel (upper left panel) and zinc (upper right panel) and corresponding price changes (lower panels) Source: World Bank

For the price processes, $\tilde{p}_{i}^{t}$, we employ the past annual prices of nickel and zinc from 1960 to 2017. Figure 1 shows the annual prices (upper panels) and the corresponding annual changes (lower 
panels $)^{3}$. Several interesting features can be observed in Figure 1. First, there is significant variation in both the levels and changes in the prices. Second, there are two extreme events in nickel prices: the yearly price increase was $166 \%$ in 1988 and $60 \%$ in 2006 . Third, an exceptional increase in the price of nickel seems to be typically followed by a corresponding decrease in the following years. Fourth, the variance in the yearly nickel price changes seems to have increased after the exceptionally high price change in 1988, suggesting a possible regime switch. Fifth, the past zinc prices display a peak in the 2000s, but also an earlier peak in the beginning of the 1970s. Finally, following the extreme cases there are no changes in the volatility of past zinc prices similar to those seen in the case of nickel prices.

The observed features are accounted for in the modelling of the price processes for nickel and zinc. They are constructed for a given initial price by simulating price changes that are randomly drawn from the historical changes depicted in the lower panels of Figure 1. Exceptional price increases and the following price drops occur in the simulations as frequently as they have appeared in the history of roughly the past 60 years. A more detailed discussion on the simulations of price processes, as well as illustrative examples of random draws, is provided in Appendix A.

\subsection{Production technology and environmental impacts}

An important feature of mining technology is that several metals are mined simultaneously. When extraction is carried out in multi-metal mines, the value of output in the objective function of the firm becomes $\sum_{i=1}^{n} \tilde{p}_{i}^{t} \tilde{q}_{i}^{t}$, where $q^{t}$ denotes quantity and, as before, the indicator $i=1 \ldots n$ indexes different metals. Moreover, technological progress and higher marginal revenues lead to mines producing units with a higher marginal cost, that is, lower-quality ore (Farrow 1985). On balance, the costs of extraction depend on the ore quality and quantity of waste rock. This can be formalized in the cost function such that $c\left(\tilde{q}_{o r e}^{t}\right)=c\left(\sum_{i=1}^{n} \alpha_{i} \tilde{q}_{i}^{t}\right)$, where $\alpha_{i}$ is a parameter describing ore quality, specifically the amount of extraction (waste rock plus metal) needed in order to gain one unit of metal $i$ (thus $\alpha_{i}>1$ ). A high parameter value means that a considerable amount of extracted material is needed to yield one unit of metal, which in turn means la ow metal content.

To model the underlying uncertainty in the production process, it is realistic to assume that learning and ramping up production takes time. The ramp-up phase can be described by a logistic function which levels off at the planned production target. Moreover, extraction activities are subject to

\footnotetext{
${ }^{3}$ An annual market price change in year $t \in\{1961, \ldots, 2017\}$ is $\frac{p^{t}-p^{t-1}}{p^{t-1}}$. The annual changes are calculated for the period 1961 to 2017.
} 
environmental accidents, which in the worst case halt production. Taking into account these uncertainties, the quantities of extraction can be modeled as $\tilde{q}^{t}\left(\phi^{j}, p r^{\psi}\right)$, where $\phi^{j}$ denotes the parameterization of the production function for learning, and $p r^{\psi}$ the probability of an environmental accident affecting extraction activities and possibly leading to a sudden drop in production.

In addition, environmental degradation is caused by a flow of effluents that is proportional to the amount of ore extracted. A major effluent is sulfate, a common by-product of mining processes. Sulfate concentrations tend to be much higher than those of metal contaminants, which means that the mass load of sulfate requiring removal is orders of magnitude higher than that of metals. (Bowell 2004)

In our modelling, the parameter $e^{t}$ describes the magnitude of the environmentally harmful impact of extraction. To take into account the stochastic features of pollution that pose a risk to water management and, ultimately, to production, we formalize the environmental impact as $\tilde{e}^{t}\left(\tilde{q}^{t}, \tilde{\varepsilon}^{t} ; p r^{\psi}, \tilde{A}\right)$. Here, a stochastic flow of polluting effluents, $\tilde{\varepsilon}^{t}$, discharged to the surrounding waters, is proportional to the quantity of extraction, $\tilde{q}^{t}$. Again, $p r^{\psi}$ is the probability of an environmental accident due to exceptionally high precipitation or like events. Accidents in water management caused by high precipitation lead to environmental damages, which we denote by $\tilde{A}$.

The indicator variable for occurrence of an environmental accident $D(A c c)$ takes the value one if there is an accident and zero otherwise. Stochastic accidents in wastewater management are typically caused by high precipitation. Hydrological models calibrated for historical data suggest that there is a probability of exceptionally high precipitation once in 100 years. Accounting for climate change, it is likely that extreme weather conditions will occur more frequently, whereby the probability of very high precipitation increases to once in 30 years. (Veijalainen 2012, Veijalainen et al. 2012) These two alternative probabilities of 1/100 years and 1/30 years are used in our simulations.

We summarize the discussion above by formalizing stochastic pollution $\tilde{e}_{i}^{t}=\tilde{\varepsilon}_{i} \tilde{q}^{t}(1-D(A c c))+D(A c c) \tilde{A}$, which means that

$$
\tilde{e}_{i}^{t}= \begin{cases}\tilde{\varepsilon}_{i} \tilde{q}^{t} & \text { if } D(A c c)=0 \\ \tilde{A} & \text { if } D(A c c)=1\end{cases}
$$

While the pollution is seen as depending on the quantity extracted when no accident occurs, it is also modelled as including randomness, which is captured by $\tilde{\varepsilon}_{i}$. In the simulations, we use a baseline amount of sulfate $\left(\mathrm{SO}_{4}\right)$ generated as a by-product of the extracted amounts and let the amount vary 
stochastically within annually observed limits. (Finnish Environment Institute 2013a, 2013b; Ramboll 2015, 2016, 2017)

To sum up and formalize the learning process in our simulations, we model the evolution of extraction amounts using a logistic function such that the quantities produced are

$$
\tilde{q}_{i}^{t}=\left\{\begin{array}{lll}
\frac{q_{i}^{t}}{1+e^{-\left(\phi_{i}^{1}+\phi_{i}^{2}\left(\phi_{i}^{3}+t\right)\right)}}\left(1+\sigma_{i}\right) & \text { if } & D(A c c)=0 \\
q_{i}^{1} & \text { if } & D(A c c)=1
\end{array}\right.
$$

where the output follows a logistic function that levels off at $q_{i}$ with metal-specific, $i$, parameters $\phi_{i}^{1}, \phi_{i}^{2}$ and $\phi_{i}^{3}, \sigma_{i}$, a random term, and no accident. In case of an accident, the extracted amount of each metal drops back to the first-period extraction level, $q_{i}^{1}$, and the ramp-up phase starts again.

Now we can discuss the calibration of the production process for our simulations. Modelling of production technology is carried out by using the historical data on quantities of a representative mining company. ${ }^{4}$ The quarterly amounts of the nickel and zinc extractions of the company are depicted by the solid lines in the upper graphs of Figure 2.

The learning process in the extractions is clearly observed in both graphs. For instance, the growth of nickel extraction is quite modest up until the second year and quarter 2 (year 2/Q2), increases very rapidly until year 3/Q2 and levels off thereafter. The parameter estimates given in the graphs of Figure 2 stand for the quarterly scale, $q_{i}$, the intercept, $\phi_{i}^{1}$, and the slope parameters, $\phi_{i}^{2}$ and $\phi_{i}^{3}$, resulting from fitting the logistic function to the observed extractions. The dashed lines show the predicted values, $\tilde{q}_{i}^{t}$, for the extracted amounts for each period. From the fitted values we observe that the extraction of nickel levels off at 4,500 tons per quarter while zinc extraction levels off at 8,500 tons per quarter. 5

\footnotetext{
${ }^{4}$ The extracted amounts are from the interims of a Finnish mining company applying bioleaching technology. The company started its operations in 2008 and was called Talvivaara by then. However, a few years later, the company was declared bankrupt because of severe production and environmental problems. The Finnish government took over the operations in 2015.

${ }^{5}$ This can be observed directly from the parameter values: $q_{1}=4500$ and $q_{2}=8500$. As $t$ increases. the predicted values from equation (2) approach $q_{1}$ and $q_{2}$ for nickel and zinc, respectively.
} 

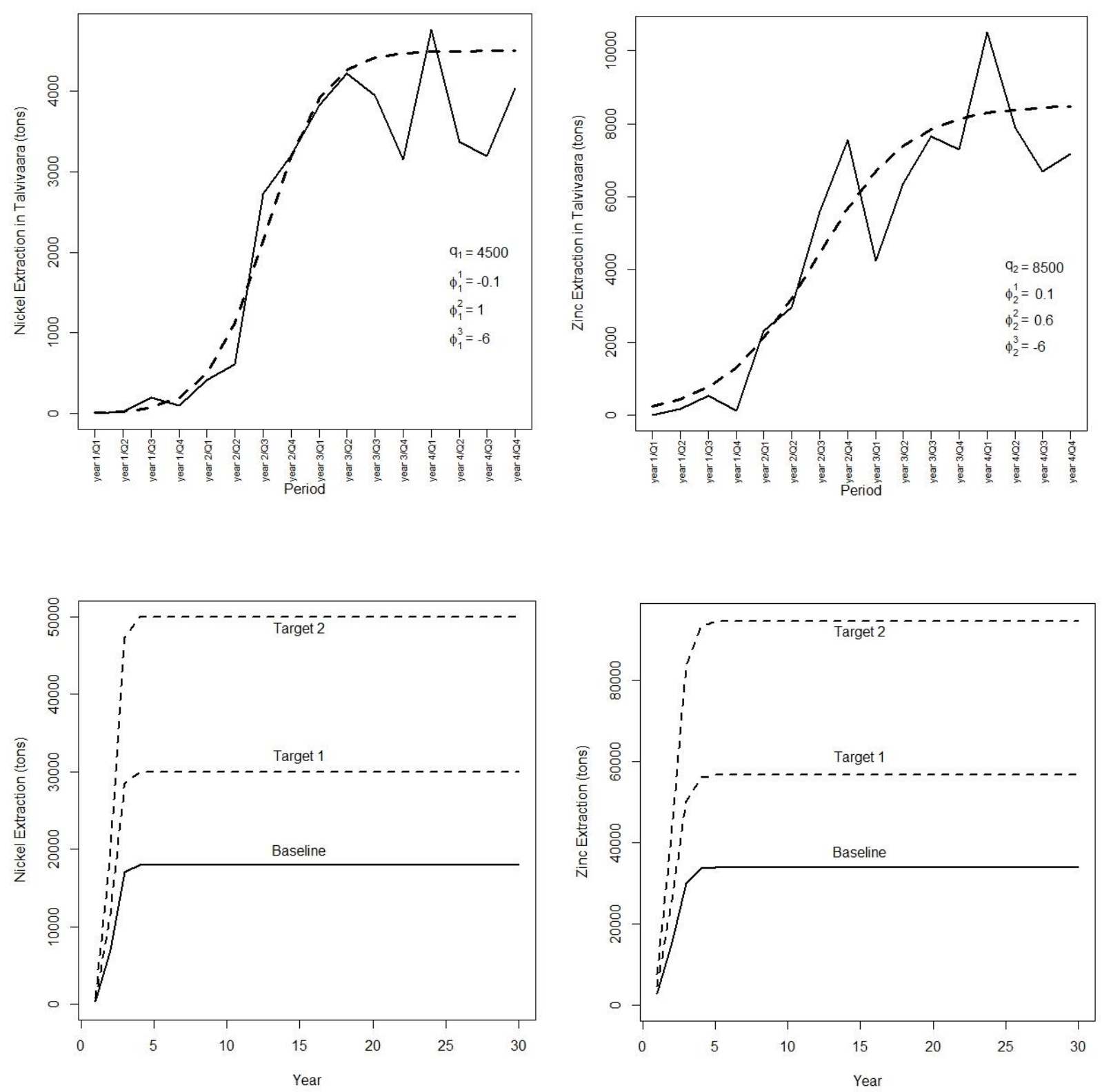

Figure 2. Nickel and zinc extraction and projected production in the protoype mine (upper panels). Alternative production scenarios (lower panels).

In order to combine the quarterly amounts of extraction with the yearly prices in our simulations, we aggregate the quarterly extractions to form an annual value. ${ }^{6}$ The solid lines in the lower graphs of Figure 2 show the yearly extractions for nickel and zinc (Baseline). They show that there is a ramp-

\footnotetext{
${ }^{6}$ The aggregation is done straightforwardly by summing up four consecutive quarters to yield a yearly extraction. For example, the first-year extraction is the sum of the extraction for the first four quarters.
} 
up phase taking place in the first four years, with extraction then levelling off from the fifth year onwards. They also show the connection to the quarterly extractions: the quarterly extractions level off at 4,500 tons and 8,500 tons for nickel and zinc and, accordingly, the annual long-run extractions level off at 18,000 tons and 34,000 tons, respectively.

The lower graphs of Figure 2 show two other production scenarios (Target 1 and Target 2). These alternative scenarios have higher extraction levels and are derived by scaling up the Baseline case such that the long-run extraction of nickel reaches 30,000 tons per year (Target 1) and 50,000 tons per year (Target 2) instead of 18,000 tons per year as in the Baseline case. The scaling is performed with the same factors for zinc. The alternative scenarios are employed in our simulations, in which we also include randomness. ${ }^{7}$

Finally, environmental regulation usually stipulates that a mine site must be restored to a condition required by public safety. At many industrial mineral operations, landscaping of tailings areas or waste rock areas and revegetation may be sufficient to meet closure requirements. Some mining operations may require an extensive program of water treatment and ongoing monitoring to ensure that there is no release of contaminants into the surrounding environment. (Mine Closure Handbook 2008, Punkkinen et al 2016) In any case, mine closure involves reclamation and rehabilitation costs that should be included in the firm's objective function. These costs materialize in the last period at $t=T$ such that the net present value of the reclamation costs can be expressed as $\rho^{T} C_{R E C}^{T}$, where $\rho^{T}$ is the discount factor.

\subsection{Summary of the model with uncertainty faced by the mining firm}

Summarizing our notation and model calibration, we have a multi-metal prototype mine that extracts two metals $(\mathrm{i}=1,2)$ with quantities $\tilde{q}_{1}^{t}$ and $\tilde{q}_{2}^{t}$. Formally, the expected profits are

$$
E\left\{\sum_{t=1}^{T} \rho^{t}\left[\sum_{i=1}^{2} \tilde{p}_{i}^{t} \tilde{q}_{i}^{t}\left(\phi_{i}, p r^{\psi}\right)-c_{o r e} \tilde{q}_{o r e}^{t}-c_{F}^{t}\right]\right\}-\rho^{T} C_{R E C}^{T}
$$

\footnotetext{
${ }^{7}$ The nickel (zinc) extraction is derived for our simulations by adding to the deterministic scenarios in the lower left (right) graph the variation between the predicted and observed extraction shown in the upper left (right) graph. More specifically, each deterministic quantity is multiplied by a random factor of $1+\sigma_{i}$ (see equation 2), where $\sigma_{i}$ is normally distributed with zero mean and standard deviation as for the observed quantities. The standard errors are calculated from the relative differences between the observed quantities and their predictions ((observed predicted)/predicted). For nickel the standard error is 0.1 and for zinc 0.4 .
} 
where the total amount extracted $\tilde{q}_{\text {ore }}^{t}=\sum_{i=1}^{2} \alpha_{i} \tilde{q}_{i}^{t}$ includes waste rock specific to metal $i$. The costs of extraction consist of a unit cost, $c_{\text {ore }}$, per quantity extracted, and annual financial costs, $c_{F}^{t}$. The operating costs, $c_{\text {ore }}$, include several components, such as costs for materials and services, personnel costs, depreciations and amortizations. These components are handled together by considering the operating cost to be constant per extracted amount of ore. In addition, in each period the firm must cover financial $\operatorname{costs} c_{F}^{t}$, which are modelled as annual fixed costs. Finally, the reclamation and rehabilitation costs show up in the objective function as closing costs at $t=T$, denoted by $C_{R E C}^{T}$.

\section{Mining firm's extraction and closing decision under uncertainty and policy intervention}

In this section, we show the exact specifications for the simulations that we use for the policy analyses to follow. Given that there is a risk of a major environmental accident and the risk may materialize in a newly started mine, it is possible that the mine declares bankruptcy. Where this is the case, an important question is what the government should do. First, we consider an extraction and closing decision under uncertainty when no policy instruments have been implemented by the government. We investigate whether it would be optimal to close the mine immediately and take care of the damages caused and costs of closing. In practice, this is determined by comparing the expected net present value of the active mine operating under uncertainty to the closing costs. These are our benchmark simulations without government intervention in section 4.1.

Second, the costs to the society could be minimized by allowing the mine to operate under strict government regulation involving economic policy instruments in use in the mining industry. We model a mining firm's decision in simulations where resource and environmental policy instruments are used to internalize externalities. We show how the alternative policy instruments can be designed and how exactly they affect the mining firm's profitability and government revenues. In section 4.2.1, we introduce applicable resource policy instruments in the modelling, and in section 4.2.2 we present relevant environmental policy instruments.

\subsection{Firm's closing decision under uncertainty}

We show the decision problem of a representative mine. It is assumed that the producer is rational and maximizes the expected discounted sum of profits. In a given period $t$, the turnover of an open mine depends on the quantities of two metals, $\tilde{q}_{1}^{t}$ and $\tilde{q}_{2}^{t}$, (nickel and zinc in the simulations) and their market prices, $\tilde{p}_{1}^{t}$ and $\tilde{p}_{2}^{t}$, respectively. Both quantities and prices are subject to uncertainty. The firm has an option to discontinue unprofitable production, but shutting down the mine entails costs for 
closure. The decision of whether to close the mine or not is based on the comparison between the net present value of the expected future income stream of an active mine and that of the closed mine.

We assume that the mine is active for $T$ periods. Profitability of the mine depends on the market prices of outputs, the quantities being extracted, and the costs of inputs being employed. Each of these margins is prone to shocks, which then affect the overall profits of the mine. The higher the uncertainty in prices and quantities, the more vulnerable the mine becomes. In addition to the price and quantity uncertainty, adoption of a new, untested mining technology may lead to water management problems, caused by excessive rain, for example. The direct cost of excessive rain for a mine is that production drops, with a probability $p r^{\psi}$, to a lower level from which it may then recover over time. Moreover, there may be unexpected environmental consequences such as leaks of contaminated process waters into the surrounding environment.

With the stochastic elements, and a discount factor $\rho^{t}$, the decision involves a comparison of the expected net present value of the income stream from an active mine and a closed mine

$$
\begin{aligned}
& N P V_{O P E N}=E\left\{\sum_{t=1}^{T} \rho^{t}\left[\sum_{i=1}^{2} \tilde{p}_{i}^{t} \tilde{q}_{i}^{t}\left(\phi_{i}, p r^{\psi}\right)-c_{o r e} \tilde{q}_{o r e}^{t}-c_{F}^{t}\right]\right\}-\rho^{T} C_{R E C}^{T} \\
& N P V_{C L O S E D}=-C_{C L O S E}
\end{aligned}
$$

where $\tilde{q}_{\text {ore }}^{t}=\sum_{i=1}^{2} \alpha_{i} \tilde{q}_{i}^{t}$. For an active mine, the reclamation cost will be paid at the end of the time horizon and thus becomes discounted, $\rho^{T} C_{R E C}^{T}$, and $C_{C L O S E}$ stands for the immediate closing costs of the mine. Note the difference between the reclamation costs, $C_{R E C}^{T}$, and the premature closing costs, $C_{C L O S E}$. The closing costs provide a justification for keeping the mine open even if it would suffer occasional losses when open. This would not be an optimal solution for the mine without the closing costs. The closing costs, $C_{C L O S E}$, for a closed mine materialize immediately and therefore do not include discounting. The closing decision is based on a comparison between the two present values. If the net present value of the open mine $\left(N P V_{O P E N}\right)$ exceeds that of the closed mine $\left(N P V_{C L O S E D}\right)$, it is worth keeping the mine open. Otherwise, shutting down the mine is the better option. The sensitivity of the closing decision to the magnitude of the closing costs is investigated in the simulations. 


\subsection{Policy intervention}

The optimal policy intervention necessitates regulation where the social costs, or shadow prices, are internalized. When environmental externalities are involved in extraction, market prices should reflect the true social costs of resource exploitation. As discussed in the context of sustainable growth and choices of clean technology (e.g., Farzin 1996, Huhtala 1998), these instruments are typically taxes. A socially optimal pricing principle for an extracted resource can be formulated as

$$
\tilde{p}^{t}=c^{\prime}\left(\tilde{q}^{t}\right)-\lambda^{t}+\theta^{t} \tilde{e}^{t}
$$

Equation (5) implies that at the optimum the price should be equal to the private marginal cost of extracting the resource and the social costs (for analytical derivation, see Appendix B). These social costs consist of the shadow price of a unit of the resource in situ, $\lambda^{t}$; this is the current opportunity cost of the resource stock and captures the value of future extraction benefits and determines the optimal conservation of resource stock. The other component is the shadow price of the pollution caused by the mine, $\theta^{t}$, weighted by the fraction that accumulates over time. In practice, equation (5) says that if the social marginal cost of extraction were correctly reflected in market prices, goods produced in extractive industries should be relatively more expensive than private production costs imply.

If, for example, the government imposes a unit-based royalty, $\lambda^{t}$, on extraction, and a Pigouvian tax, $\theta^{t}$, on pollution, the government collects as tax revenue $T_{G}^{t}=\lambda^{t} \tilde{q}_{\text {ore }}^{t}+\theta^{t} \tilde{e}^{t} \tilde{q}_{\text {ore }}^{t}$. The tax revenues are a form of compensation to the government, or the general public, as the resource owner for the depletion of the nonrenewable resource and environmental degradation.

There is a considerable literature on the implementation of corrective taxes and the challenges faced in a distorted world (see, e.g., Dasgupta and Heal, 1979, Boadway and Keen, 2015). Lund (2009) has emphasized that little attention has been paid to tax levels in the design of policy instruments. Setting tax levels is especially difficult when there are uncertainties related to resource prices, mining technologies, and environmental impacts. To address this challenge, we next elaborate the alternative policy instruments relevant to the operating environment of a mining firm and the stochastic features that characterize the industry.

\subsubsection{Resource policy instruments}

Here we consider three alternative resource policy instruments by which the government may extract resource rents: a royalty, an ad valorem tax and a corporate tax. 
The resource rent, its in situ value, is the shadow price $\lambda^{t}$ in equation (5). Taxation of the resource rent can be implemented as a royalty paid on the total amount of ore extracted from the ground. The royalty would be a quantity-based resource tax, and government revenues would amount to $\lambda \tilde{q}_{\text {ore }}^{t}=$ $\lambda \sum_{i=1}^{n} \alpha_{i} \tilde{q}_{i}^{t}$

If there is a royalty, $\lambda$, to be paid on the amount of ore, the expected net present value from the mining becomes

$$
N P V_{O P E N}=E\left\{\sum_{t=1}^{T} \rho^{t}\left[\sum_{i=1}^{2} \tilde{p}_{i}^{t} \tilde{q}_{i}^{t}\left(\phi_{i}, p r^{\psi}\right)-c_{\text {ore }} \tilde{q}_{\text {ore }}^{t}-c_{F}^{t}-\lambda \tilde{q}_{\text {ore }}^{t}\right]\right\}-\rho^{T} C_{R E C}^{T}
$$

Alternatively, a resource tax could be implemented as an ad valorem tax, $\tau^{A D}$, that is paid on the value of output, or marginal revenues, $\tau^{A D} \sum_{i=1}^{n} \tilde{p}_{i}^{t} \tilde{q}_{i}^{t}$. With an ad valorem tax in place, the expected net present value of the income stream from an active mine becomes

$$
N P V_{O P E N}=E\left\{\sum_{t=1}^{T} \rho^{t}\left[\left(1-\tau^{A D}\right)\left(\sum_{i=1}^{2} \tilde{p}_{i}^{t} \tilde{q}_{i}^{t}\left(\phi_{i}, p r^{\psi}\right)\right)-c_{\text {ore }} \tilde{q}_{\text {ore }}^{t}-c_{F}^{t}\right]\right\}-\rho^{T} C_{R E C}^{T}
$$

Finally, as governments apply a standard corporate income tax system for all companies, instead of a separate resource tax it would be possible to levy a higher corporate tax rate, $\tau^{C O R P}$, on mining companies than on others. Consequently, government tax revenue would vary with the profitability of the mining project, or $\tau^{\operatorname{CORP}}\left[\sum_{i=1}^{n} \tilde{p}_{i}^{t} \widetilde{q}_{i}^{t}-c_{\text {ore }}\left(\widetilde{q}_{\text {ore }}^{t}\right)-c_{F}^{t}\right]$.

Applying a corporate tax rate $\tau^{C O R P}$ leads to an expected net present value of the form

$$
N P V_{O P E N}=E\left\{\sum_{t=1}^{T} \rho^{t}\left(1-\tau^{C O R P}\right)\left[\sum_{i=1}^{2} \tilde{p}_{i}^{t} \tilde{q}_{i}^{t}\left(\phi_{i}, p r^{\psi}\right)-c_{\text {ore }} \tilde{q}_{\text {ore }}^{t}-c_{F}^{t}\right]\right\}-\rho^{T} C_{R E C}^{T}
$$

The specific corporate tax rate applied to the mining industry would ensure payment of the compensation sought by the government for the resource rent. 


\subsubsection{Environmental policy instruments}

In addition to extracting rents through taxation, one reason for the government to intervene in the mining sector is the potentially harmful environmental impacts that mining operations entail. To internalize environmental externalities, a Pigou tax could be used as incentive for pollution control (Pigou 1920). This is what the shadow price $\theta^{t}$ suggests in equation (5), where the Pigou tax is proportional to polluting effluents, $e^{t}$, accumulating over time.

Moreover, environmental accidents call for an additional set of alternative policy instruments. In practice, the policy instruments available are fines levied when environmental accidents occur, financial sureties, and up-front payments to liability funds. A payment to a liability fund covering the whole mining industry differs from the other two in that it is non-refundable; that is, it is paid into to a fund regardless of whether an accident occurs or not during the lifetime of the particular mine. In contrast, a surety provides funds to the government associated with a rehabilitation program of the specific mining operations in question. In the following, we denote fines by $\Psi$, up-front payments to a liability fund (set up for the mining industry) by $\mathrm{P}$, and a surety bond by B. Moreover, as discussed earlier, the probability of an accident is denoted by $p r^{\psi}$. All the alternative policy instruments are considered as means of environmental regulation in the following simulations.

First, we have a Pigou tax, $\theta$, which is implemented per ton of effluent, proportional to amount of ore extracted $\varepsilon_{i} \tilde{q}_{o}^{t}$ such that

$$
N P V_{O P E N}=E\left\{\sum_{t=1}^{T} \rho^{t}\left[\sum_{i=1}^{2} \tilde{p}_{i}^{t} \tilde{q}_{i}^{t}\left(\phi_{i}, p r^{\psi}\right)-c_{\text {ore }} \tilde{q}_{\text {ore }}^{t}-c_{F}^{t}-\theta \varepsilon_{i} \tilde{q}_{\text {ore }}^{t}\right]\right\}-\rho^{T} C_{R E C}^{T}
$$

The second instrument, the mandatory up-front payment, $\mathrm{P}$, to a liability fund from which the government can appropriate money for mine reclamation or environmental protection, can be represented as follows

$$
N P V_{O P E N}=E\left\{\sum_{t=1}^{T} \rho^{t}\left[\sum_{i=1}^{2} \tilde{p}_{i}^{t} \tilde{q}_{i}^{t}\left(\phi_{i}, p r^{\psi}\right)-c_{\text {ore }} \tilde{q}_{\text {ore }}^{t}-c_{F}^{t}\right]\right\}-\mathrm{P}-\rho^{T} C_{R E C}^{T}
$$


The third form of policy instrument is a surety. A surety bond is a firm's agreement to provide funds to a third party or government to cover closing and reclamation costs. Where the surety bond, B, is applied, the expected net present value of the income stream from an active mine is

$$
N P V_{O P E N}=E\left\{\sum_{t=1}^{T} \rho^{t}\left[\sum_{i=1}^{2} \tilde{p}_{i}^{t} \tilde{q}_{i}^{t}\left(\phi_{i}, p r^{\psi}\right)-c_{o r e} \tilde{q}_{o r e}^{t}-c_{F}^{t}\right]\right\}-\mathrm{B}+\left[(1-D(A c c)) \mathrm{B}-C_{R E C}^{T}\right] \rho^{T}
$$

where $D\left(p r^{\psi}\right)$ is a dichotomous indicator variable for occurrence of an environmental accident with a probability $p r^{\psi}$.

Finally, environmental regulation may stipulate that a firm must pay a fine, $\Psi$, as compensation for environmental damage caused by accidents such as leakage of contaminated water into the environment

$$
N P V_{O P E N}=E\left\{\sum_{t=1}^{T} \rho^{t}\left[\sum_{i=1}^{2} \tilde{p}_{i}^{t} \tilde{q}_{i}^{t}\left(\phi_{i}, p r^{\psi}\right)-c_{o r e} \tilde{q}_{o r e}^{t}-c_{F}^{t}-\Psi^{t}\left(\tilde{A} ; p r^{\psi}\right)\right]\right\}-\rho^{T} C_{R E C}^{T}
$$

where the fine depends on the damage caused, $\tilde{A}$, and $\Psi$ is subject to randomness in each period.

\section{Benchmark simulations and sensitivity analysis for a closing decision}

This section illustrates the decision making of the owner of a mine whose long-term profitability is affected by uncertainties in the operating environment. We start with a brief description of such a mine and then continue by carrying out simulations for the profitability of the mine under alternative assumptions on the key parameters, specifically, price uncertainty, production levels and environmental impacts.

The prototype mine used in our simulations has stylized features of an existing multi-metal mine in northern Finland. The mineral stock of the mine is one of the largest sulfide nickel deposits in Europe 
with estimated reserves of 1,550 megatons. (See Mudd and Jowitt, 2014) ${ }^{8}$ Here, the main commodities extracted from the representative mine are nickel and zinc.

The details of the prototype mine are given in Table 1 . The simulations are carried out over a horizon of 30 years. The operating costs (USD 43.7/ton of ore) and net financial costs (USD 39.6M/year) are calculated from the materialized profit and loss accounts of the mine. ${ }^{9}$ The immediate closing costs of the mine, $C_{C L O S E}$, assume premature closure due to an environmental accident or other unforeseen event (USD 200 million). ${ }^{10}$ If the mine closes normally at the end of its lifecycle, the reclamation and remediation costs, $C_{R E C}$, are paid then (USD 50 million). ${ }^{11} \mathrm{~A}$ discount factor of 0.95 is used to account for the timing of the profits and costs. An environmental accident occurs with a likelihood of 1/100.

Table 1. Details of the prototype mining project - Benchmark

\begin{tabular}{|c|c|c|}
\hline Project Type & \multicolumn{2}{|c|}{ Heap Leaching } \\
\hline Production Life Length, $T$ (years) & \multicolumn{2}{|c|}{30} \\
\hline Discount Factor, $\rho^{t}$ & \multicolumn{2}{|c|}{0.95} \\
\hline Operating Costs, $c_{\text {ore }}(\$ /$ ton of ore $)$ & \multicolumn{2}{|c|}{43.7} \\
\hline Net Financial Costs, $c_{F}^{t}(\mathrm{M} \$$ /year $)$ & \multicolumn{2}{|c|}{39.6} \\
\hline Closing Cost, $C_{C L O S E}(\mathrm{M} \$)$ & \multicolumn{2}{|c|}{200} \\
\hline Reclamation Cost, $C_{R E C}(\mathrm{M} \$)$ & \multicolumn{2}{|c|}{50} \\
\hline Likelihood of Environmental Accident, $p r^{\psi}$ & \multicolumn{2}{|c|}{$1 / 100$} \\
\hline Price in 1 st year $(\$ /$ ton $)$ & $\begin{array}{c}\text { Nickel, } p_{1}^{1} \\
10,000 \\
\end{array}$ & $\begin{array}{c}\text { Zinc, } p_{2}^{1} \\
2,000\end{array}$ \\
\hline Long-Run Production (ton/year) & Nickel, $q_{1}^{1}$ & Zinc, $q_{2}^{1}$ \\
\hline - Baseline & 18,000 & 34,000 \\
\hline - Target 1 & 30,000 & 57,000 \\
\hline - Target 2 & 50,000 & 94,000 \\
\hline
\end{tabular}

The first-year metal prices given in Table 1 are based on their historical average prices. The three production scenarios (Baseline, Target 1 and Target 2) are the ones depicted in the lower graphs of

\footnotetext{
${ }^{8}$ The mine is in a region called Talvivaara, which was also the name of the company by the time it started its operations in 2008. The company's annual report from 2009 provides estimates reserves at 1,004 megatons; three years later an estimate of 2,053 megatons was reported.

${ }^{9}$ These values have been collected from the annual reports.

${ }^{10}$ Premature closure may be more costly when site cleanup involves treatment of hazardous substances released in an environmental accident.

${ }^{11}$ The closing costs are estimated based on "Mine Closure Handbook" (2008) and an Investigation Report by a Finnish Safety Investigation Authority (2014).
} 
Figure 2. Changes in the inventories are disregarded in the analysis. ${ }^{12}$ In the simulations, the parameters given in Table 1 are first used as benchmark values; thereafter, numerous sensitivity analyses are carried out with varied values of the parameters of interest.

Our simulations illustrate how uncertainty affects the profitability of mining operations and the decision as to whether a mine should be closed or not. The first set of simulation results is carried out without considering social costs, that is, intervention in the form of policy instruments, to see whether mining is economically viable with private costs only. We run 1,000 simulations, and the mine is active for 30 years $(T=30)$ in each simulation.

Figure 3 shows a frequency distribution for the net present value of the mine from the 1,000 simulations based on the benchmark parameter values (Table 1) and the long-run production level Target 1 (30,000 tons of nickel and 57,000 tons of zinc per year). The figure shows that in only relatively few simulations is the net present value (NPV) over the 30 years positive, whereas in most of the cases it is negative (the values lie to the left of the dashed vertical line indicating a net present value of zero on the horizontal axis). The expected average net present value of the open mine is negative (denoted by the solid vertical line $N P V_{O P E N}$ in Figure 3), which corresponds to a loss of USD 2,800 million. The net present value of a closed mine ( $\left.N P V_{C L O S E D}\right)$ is negative as well due to the closing cost of USD 200 million, but the average loss is still smaller than the average NPV of the open mine. Therefore, an "average" mine should be closed under such conditions to avoid the expected losses.

Some simulations yield negative net present values, but still suggest keeping the mine open. In Figure 3 , these cases lie between the vertical line describing the zero net present value (dashed line) and the net present value of the closed mine $\left(N P V_{C L O S E D}\right)$. All in all, only 86 of the $1,000(8.6 \%)$ individual simulations suggest that the mine should remain open. In contrast, 914 cases suggest that the mine should be closed (these simulation outcomes lie to the left of the vertical line NPV $\left.V_{C L O S E D}\right) .{ }^{13}$

\footnotetext{
12 This corresponds to a situation where storage is prohibitively costly, and all extracted ore is instantly sold. This is a common assumption in the literature (see, e.g., Mason 2001).

${ }^{13}$ Our calibration of parameters for the simulation model is in line with the (ex post) profitability and financial results of the Talvivaara mine, currently operated by the company Terrafame, in which the state is the majority owner. Since 2015 the company has recorded losses in each financial year (Terrafame Financial Review, March 4, 2020)
} 


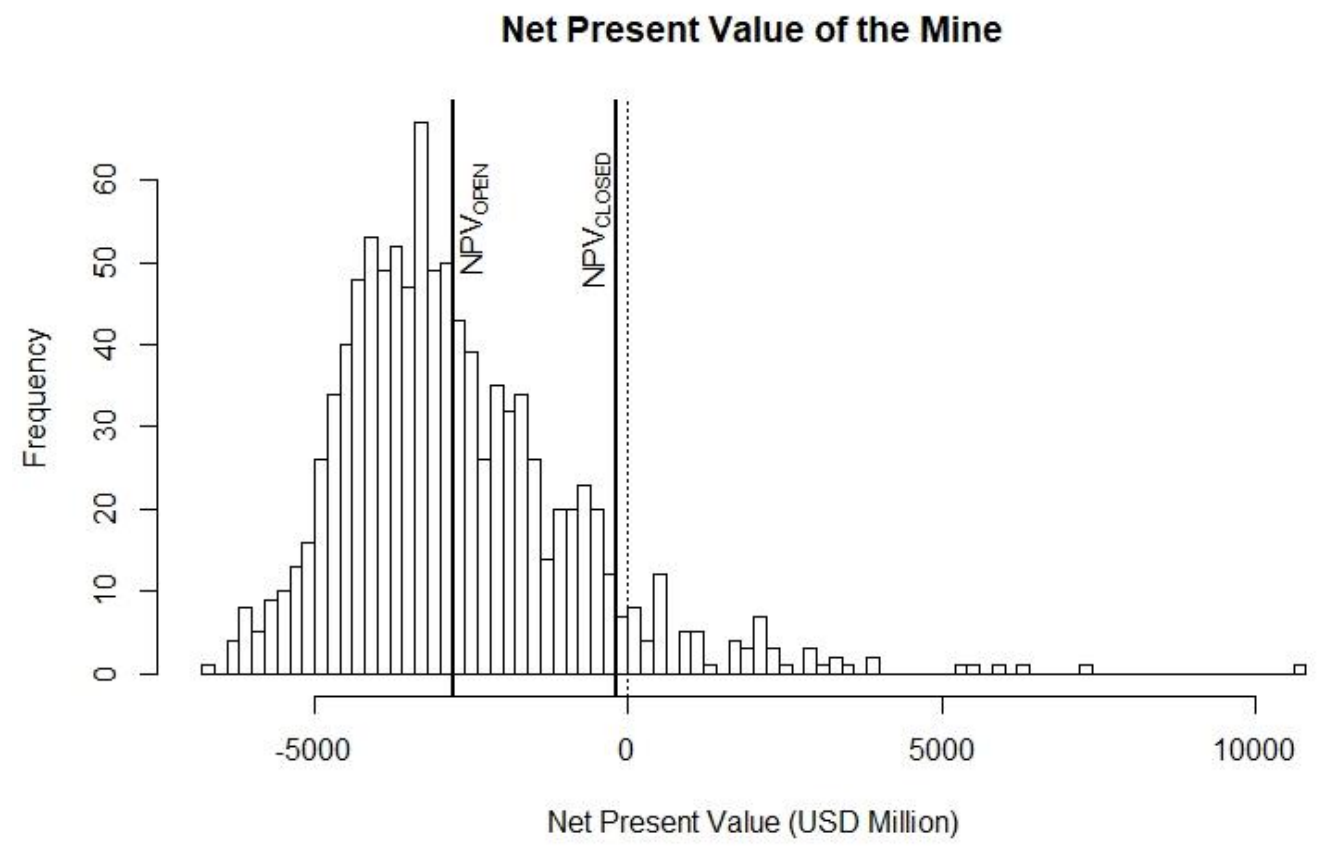

Figure 3. Simulated net present values for benchmark case with production level of Target 1

In addition to the Benchmark set of simulations above, we run several simulations to investigate the sensitivity of outcomes to production levels, closing costs and other key parameter values in Table 1 . The results are summarized in Table 2. The average NPVs of an open mine and the share of simulation outcomes with $N P V_{O P E N}>N P V_{C L O S E D}$ (given by $\%$ in the parentheses) are reported. ${ }^{14}$ The mine chooses in each case whether to remain open or to close by comparing the average net present value of the mine when open to that of mine if closed.

The uppermost panel of Table 2 shows the results for the Benchmark parameters in Table 1. In addition to Benchmark panel (i), we report three panels of robustness checks with respect to the discount factor (ii), the metal prices (iii) and the operating costs (iv). In all panels (i-iv), the simulation outcomes are considered with respect to closing costs $\left(C_{C L O S E}\right.$ varies from USD200 million to USD50 million by row) and production levels (Baseline, Target 1, Target 2 by column; see also Figure 2 for the production levels).

\footnotetext{
${ }^{14}$ In each set of 1,000 simulations, we compare the average net present value of the firm if it remains open $\left(N P V_{O P E N}\right)$ to the net present value if it closes $\left(N P V_{C L O S E D}\right)$.
} 
Table 2. Average net present value of an open mine, million USD (M\$) (\% of 1,000 simulations when $N P V_{O P E N}>N P V_{C L O S E D}$ in parentheses)

\begin{tabular}{|c|c|c|c|}
\hline \multicolumn{4}{|l|}{ Benchmark (i) } \\
\hline Costs / Production Level & Baseline & Target 1 & Target 2 \\
\hline$C_{R E C}=\$ 50 M \& C_{C L O S E}=\$ 200 M$ & $-1,916(7.3 \%)$ & $-2,771(8.6 \%)$ & $-4,196(9.5 \%)$ \\
\hline$C_{R E C}=\$ 50 M \& C_{C L O S E}=\$ 100 M$ & $-1,916(6.7 \%)$ & $-2,771(8.3 \%)$ & $-4,196(9.1 \%)$ \\
\hline$C_{R E C}=\$ 50 M \& C_{C L O S E}=\$ 50 M$ & $-1,916(6.3 \%)$ & $-2,771(7.5 \%)$ & $-4,196(9.0 \%)$ \\
\hline \multicolumn{4}{|l|}{ High Discount (ii) } \\
\hline Costs / Production Level & Baseline & Target 1 & Target 2 \\
\hline$C_{R E C}=\$ 50 M \& C_{C L O S E}=\$ 200 M$ & $-2,474(7.8 \%)$ & $-3,584(9.4 \%)$ & $-5,107(11.6 \%)$ \\
\hline$C_{R E C}=\$ 50 M \& C_{C L O S E}=\$ 100 M$ & $-2,474(7.1 \%)$ & $-3,584(9.1 \%)$ & $-5,107(11.2 \%)$ \\
\hline$C_{R E C}=\$ 50 M \& C_{C L O S E}=\$ 50 M$ & $-2,474(7.0 \%)$ & $-3,584(8.8 \%)$ & $-5,107(11.0 \%)$ \\
\hline \multicolumn{4}{|l|}{ High Prices (iii) } \\
\hline Costs / Production Level & Baseline & Target 1 & Target 2 \\
\hline$C_{R E C}=\$ 50 M \& C_{C L O S E}=\$ 200 M$ & $-151(44.8 \%)$ & $171(49.6 \%)$ & $708(51.9 \%)$ \\
\hline$C_{R E C}=\$ 50 M \& C_{C L O S E}=\$ 100 M$ & $-151(41.7 \%)$ & $171(47.7 \%)$ & $708(51.0 \%)$ \\
\hline$C_{R E C}=\$ 50 M \& C_{C L O S E}=\$ 50 M$ & $-151(40.4 \%)$ & $171(46.4 \%)$ & $708(50.9 \%)$ \\
\hline \multicolumn{4}{|l|}{ Low Cost (iv) } \\
\hline Costs / Production Level & Baseline & Target 1 & Target 2 \\
\hline$C_{R E C}=\$ 50 M \& C_{C L O S E}=\$ 200 M$ & $730(81.8 \%)$ & $1,640(87.0 \%)$ & $3,154(89.9 \%)$ \\
\hline$C_{R E C}=\$ 50 M \& C_{C L O S E}=\$ 100 M$ & $730(78.0 \%)$ & $1,640(85.1 \%)$ & $3,154(88.6 \%)$ \\
\hline$C_{R E C}=\$ 50 M \& C_{C L O S E}=\$ 50 M$ & $730(75.8 \%)$ & $1,640(83.9 \%)$ & $3,154(88.2 \%)$ \\
\hline
\end{tabular}

Note: 1000 simulations. Nickel production levels are for Baseline, Target 1 and Target 2, 18,000 ton/year, 30,000 ton/year and 50,000 ton/year, respectively. Zinc production levels are for Baseline, Target 1 and Target 2, 34,000 ton/year, 56,700 ton/year and 94,452 ton/year, respectively. The details for the simulation parameters in Benchmark panel are given in Table 1. Discount factor in High Discount panel is 0.97. The first-year nickel and zinc prices in the High Prices panel are USD 15,000/ton and USD 3,000/ton, respectively. In the Low Cost panel, the operating costs are USD 20/ton of ore.

From Panel (i) of Table 2, we take a closer look at a simulation outcome that corresponds to the distribution presented in Figure 3. The table shows that at the Target 1 production level, and with the closing costs at their highest, or USD 200 million, the average net present value of the mine is USD $-2,771$ million, and only $8.6 \%$ of simulations result in the net present value of an open mine being greater than that of a closed one (i.e., $\left.N P V_{O P E N}>N P V_{C L O S E D}\right)$. Furthermore, in Panel (i), the net present value of the mine is negative for all the production levels, and the loss varies roughly between USD 2,000 million and USD 4,000 million. Importantly, the smaller the closing costs $\left(C_{C L O S E}\right)$, the more likely the prototype mine should be closed for economic reasons at each production level. Only about $6-10 \%$ of the simulations suggest that the mine should continue operations. 
Similar conclusions arise from our robustness check using a high discount factor and is shown in Panel (ii) in Table 2. The net present values of the mine are heavily negative, and more negative than the net present value of the closed mine. Moreover, a larger scale of production, or Target 2, makes the losses even larger as, obviously, the projected revenues do not cover the production costs with expanding output.

Panel High Prices (iii) in Table 2 reports the sensitivity results for increased first-year metal prices, that is, USD 15,000/ton for nickel and USD 3,000/ton for zinc. These prices are at the high end of the historically observed prices for the metals (see the upper graphs of Figure 1). With the higher prices the average net present values are larger than the net present value of the closed mine (with a loss of USD $50-200$ million) at the high production levels Target 1 and 2 . About 40-50\% of simulations show the net present value of an open mine being larger than a closed one.

Finally, we consider the simulation results for cases where the operating costs for ore extraction are roughly halved to USD 20/ton from the benchmark value of Table $1 .{ }^{15}$ In these scenarios, shown in Panel Low-Cost (iv) in Table 2, all the net present values of the mine are positive, and thus also larger than the net present value of the mine if closed. About $75-90 \%$ of the simulations suggest that the mine should not be closed, as its net present value would be larger by continuing mining than closing the operations.

We can summarize our simulation results regarding the decision of mine closure as follows. Choosing a slightly higher discount factor than in the benchmark, the optimal decision would still be to close the mine. In contrast, lower operating costs and higher prices than those in the benchmark case would increase the average net present value of the mine. The shaded cells in Table 2 show the cases in which the average net present value of an open mine remains positive. Yet, the higher initial prices of metals, which are volatile and may temporarily surge to record peaks, do not make the mining firm as likely to remain open as the permanently low operating costs. The given volatile world market commodity prices, the mining firm can improve the efficiency of its production by lowering operating costs, a measure which would be important for profitability over the whole lifecycle of the facility.

\footnotetext{
${ }^{15}$ Heap leaching is not a labor-intensive process, and the related operating costs are not very sensitive to the size of operation; for a discussion on heap leaching costs, and economic comparison of alternative processing technologies, see, e.g., Kappes (2002), Wedderburn (2010), Oxley and Barcza (2013) and Trujillo et al (2014).
} 


\section{Simulations with policy interventions}

\subsection{Simulations with resource policy instruments}

As noted above, we have three resource policy instruments whose purpose is to secure a resource rent for the government from the extraction of nonrenewable resource. As shown in section 4.2.1, the alternative policy interventions make use of a royalty, an ad valorem tax and a corporate tax. In the empirical literature, there is little discussion on the optimal levels of taxes or royalties that should be applied (Lund 2009). We use the simulations to investigate the alternative policy instruments. Each instrument is introduced separately in the firm's profit-maximization problem.

The top panel of Table 3 reports the previous results for the average net present value with low operating costs corresponding to the lowest panel, Low-Cost (iv) in Table 2. This is a benchmark where we do not have any policy instrument and the government does not collect any revenue.

Recall that the net present value is highly positive for all the production levels (Baseline, Target 1, Target 2). The next three panels of Table 3 show the upper limits for three alternative resource policy instruments for each of the three production levels (Baseline, Target 1 and Target 2) when the firm's NPV becomes zero. In other words, we find out the largest value of the government revenues for each policy instrument that leaves the mine with zero profits. Simulating the maximum possible values for these instruments facilitates a comparison of the instruments with regard to the magnitude of potential distortions they generate (with respect to the firm's profits vs. government revenues) and provides knowledge on feasible instrument levels when a combination of alternative instruments is studied further in section 6.3.

Our simulations show that at maximum the royalty is about USD 6-10 per ton of ore extracted, the ad valorem tax rate on output is between $19 \%$ and $30 \%$, and the corporate tax rate is between $67 \%$ and $86 \%$. Intervention with these rates at the corresponding production levels would leave the mine owner with zero profits on average over time.

Table 3 shows that the government collects roughly similar revenues under each policy instrument: at the Baseline production level revenues are about USD 300 million, at Target 1 production about USD 700 million and at Target 2 about USD 1,400 million. Thus, in these cases, the government collects royalty/tax revenues of several hundred million dollars in net present value over the lifecycle of the mine, or in 30 years. In theory, the government can reap the profits from the firm using our policy design; clearly, this is not the case in practice. For example, one observation from the table is that the break-even corporate tax rates for zero profits are extremely high, almost $90 \%$. 
Table 3. Simulation results under uncertainty and resource policy intervention

\begin{tabular}{|c|c|c|c|}
\hline \multicolumn{4}{|c|}{ Low Cost - No Policy Instrument } \\
\hline Production Level & Baseline & Target 1 & Target 2 \\
\hline Policy Instrument & None & None & None \\
\hline Government Revenue (average NPV, M\$) & 0 & 0 & 0 \\
\hline Firm Net Present Value (average NPV, M\$) & 730 & 1,640 & 3,154 \\
\hline \multicolumn{4}{|l|}{ Low Cost + Royalty } \\
\hline Production Level & Baseline & Target 1 & Target 2 \\
\hline Royalty $\lambda(\$ /$ of ore $)$ & 5.9 & 8.2 & 9.6 \\
\hline Government Revenue (average NPV, M\$) & 299 & 694 & 1,353 \\
\hline Firm Net Present Value (average NPV, M\$) & 0 & 0 & 0 \\
\hline \multicolumn{4}{|l|}{ Low Cost + Ad Valorem Tax } \\
\hline Production Level & Baseline & Target 1 & Target 2 \\
\hline Ad Valorem Tax, $\tau^{\mathrm{AD}}(\%)$ & 19 & 26 & 30 \\
\hline Government Revenue (average NPV, M\$) & 305 & 697 & 1,340 \\
\hline Firm Net Present Value (average NPV, M\$) & 0 & 0 & 0 \\
\hline \multicolumn{4}{|l|}{ Low Cost + Corporate Tax } \\
\hline Production Level & Baseline & Target 1 & Target 2 \\
\hline Corporate Tax, $\tau^{\mathrm{CORP}}(\%)$ & 67 & 80 & 86 \\
\hline Government Revenue (average NPV, M\$) & 323 & 732 & 1,415 \\
\hline Firm Net Present Value (average NPV, M\$) & 0 & 0 & 0 \\
\hline
\end{tabular}

Note: 1000 simulations. Baseline, Target 1 and Target 2 production levels are given in Table 1.

For comparison, and as a reality check, the current corporate tax rate varies internationally between $0 \%$ and $55 \%$, with the global average being $23.79 \%$ and the EU average 21.16\% (KPMG 2019). ${ }^{16}$ Moreover, international tax competition is a relevant concern to be tackled by policy makers in the international community, as has been discussed in the literature (see, e.g., Devereux and Loretz 2013, Dharmapala 2014, Heckemeyer and Overesch 2017). Effective tax rates for multinational mining companies can be much lower in practice than statutory rates due to considerations such as varying definitions of the tax base from country to country (for challenges in the mineral-sector tax systems, transfer pricing and other tax minimization schemes, see, e.g., Finér and Ylönen 2017 and Otto 2018).

\footnotetext{
${ }^{16}$ In 2019, the United Arab Emirates had the highest corporate tax rate (55\%) for its oil companies. The second highest rate, $36 \%$, was applied in Surinam. Countries with zero tax rates include Bahrain, Bermuda and the Cayman Islands. (KPMG 2019)
} 
The purpose of the previous simulation exercises is to find the maximum values for the instruments that leave the mining firm without profits. What we also observe from the exercise is the cost of taxation in terms of firm's average net present value. When appropriating the firm's economic rent, the government collects about half of the initial NPV of the firm (before intervention) as revenues. Table 3 shows that the efficiency in collecting revenues does not differ by instrument.

All in all, the simulations suggest that the levels of the policy instruments in the form of a royalty, an ad valorem tax and a corporate tax (per the alternative production levels reported in Table 3) could be very high at their maxima when implemented one at a time and separately. We return to the realism of this kind of policy later, but we first carry out similar exercises for the level of environmental policy instruments.

\subsection{Simulations with environmental policy instruments}

Next, we consider the simulation results with alternative environmental policy instruments. When choosing the magnitude, or level, of each instrument, the logic is the same as above for resource policies. The levels of the policy instruments are chosen such that the mining firm remains roughly indifferent between closing the mine or keeping it open; that is, it makes zero profits. Again, like Table 3, the first panel in Table 4 shows the results for low operating costs and without any policy instruments for the three production levels. In the lower panels, four policy instruments are considered: a Pigou tax, an up-front payment, a surety bond and a fine.

The maximum levels of the different instruments from Table 4 can be summarized as follows. The mine makes zero profits when the Pigou tax is in the range of USD 2,500-4,100 per ton of effluent (sulphate SO4), with the production ranging from the baseline to the highest target level. ${ }^{17}$ The size of the up-front liability payment could be in the range of USD 660-3,000 million and of the surety bond USD 850-3,800 million; at these levels, the mine could remain open, albeit marginally. The required surety bond is higher than the liability payment, which will not be returned to the firm even if there is no environmental accident.

\footnotetext{
${ }^{17}$ To the best of our knowledge there are no estimates on the marginal external costs of sulfate on water quality. The potentially harmful impacts of sulfate on health (e.g,. through drinking water) are managed by ambient water quality guidelines (e.g. Meays and Nordin 2013). What is known is that treating sulfate is expensive (USD $1.3 / \mathrm{m}^{3}$ ) when there is no plan in place for managing sulfate impacts during mining operations (Sharp 2012).
} 
Table 4. Simulation results under uncertainty and environmental policy intervention

\begin{tabular}{|c|c|c|c|}
\hline \multicolumn{4}{|c|}{ Low Cost - No Policy Instrument } \\
\hline Production Level & Baseline & Target 1 & Target 2 \\
\hline Policy Instrument & None & None & None \\
\hline Government Revenue (average NPV, M\$) & 0 & 0 & 0 \\
\hline Firm Net Present Value (average NPV, M\$) & 730 & 1,640 & 3,154 \\
\hline \multicolumn{4}{|l|}{ Low Cost + Pigou Tax } \\
\hline Production Level & Baseline & Target 1 & Target 2 \\
\hline Pigou Tax, $\theta$ ( $\$ / t$ of effluent $)$ & 2,500 & 3,500 & 4,100 \\
\hline Government Revenue (average NPV, M\$) & 297 & 693 & 1,353 \\
\hline Firm Net Present Value (average NPV, M\$) & 0 & 0 & 0 \\
\hline \multicolumn{4}{|c|}{ Low Cost + Up-Front Payment } \\
\hline Production Level & Baseline & Target 1 & Target 2 \\
\hline Up-Front Payment P, (M\$) & 660 & 1,500 & 2,950 \\
\hline Government Revenue (average NPV, M\$) & 660 & 1,500 & 2,950 \\
\hline Firm Net Present Value (average NPV, M\$) & 0 & 0 & 0 \\
\hline \multicolumn{4}{|l|}{ Low Cost + Surety Bond } \\
\hline Production Level & Baseline & Target 1 & Target 2 \\
\hline Surety Bond, B (M\$) & 850 & 1,960 & 3,800 \\
\hline Government Revenue (average NPV, M\$) & 658 & 1,517 & 2,941 \\
\hline Firm Net Present Value (average NPV, M\$) & 0 & 0 & 0 \\
\hline \multicolumn{4}{|c|}{ Low Cost + Fine, $\mathrm{pr}^{\Psi}=1 / 100$} \\
\hline Production Level & Baseline & Target 1 & Target 2 \\
\hline Fine, $\Psi(\mathrm{M} \$)$ & 5,500 & 13,000 & 25,000 \\
\hline Government Revenue (average NPV, M\$) & 311 & 734 & 1,412 \\
\hline Firm Net Present Value (average NPV, M\$) & 0 & 0 & 0 \\
\hline \multicolumn{4}{|l|}{ Low Cost + Fine, $\operatorname{pr}^{\Psi}=1 / 30$} \\
\hline Production Level & Baseline & Target 1 & Target 2 \\
\hline Fine, $\Psi(\mathrm{M} \$)$ & 1,500 & 3,500 & 6,800 \\
\hline Government Revenue (average NPV, M\$) & 306 & 715 & 1,389 \\
\hline Firm Net Present Value (average NPV, M\$) & 0 & 0 & 0 \\
\hline
\end{tabular}

Note: 1000 simulations. Baseline, Target 1 and Target 2 production levels are given in Table 1.

The fine that would leave the mine marginally operational varies between USD 5,500-25,000 million when the probability of an accident is $1 / 100$. When the probability is increased to $1 / 30$, the fine varies between USD 1,500-6,800 million (lowest panel in Table 4). The reduction in the fine follows from the fact that it must be paid more often when the probability of an accident increases. On the other hand, a threefold increase in the probability of an accident (from 1/100 to 1/30) has a large impact on 
the size of the fine that makes the mine marginally viable. For the lower probability, the break-even fines are about $1 / 3$ of those for the higher probability. The government revenue is about the same in these cases, but the size of the fines must be huge, unrealistically high in fact, for the given accident probabilities.

Overall, regarding the government revenue from the policy instruments in Table 4, the liability payment and the surety bond generate rather similar and high revenues for the government, whereas the Pigou taxes and fines generate the lowest revenues of the policy instruments. Recall that the NPV profits of the mining firm are by construction the same, or zero. Given the design, the up-front payment and surety bond guarantee the government roughly similar income, or revenues.

\subsection{Simulations with simultaneous resource and environmental policy instruments}

The previous simulations show the range of the levels of policy instruments that could be implemented in principle, one by one, with the mining firm being left without profits. This is not a very realistic policy scenario. Now that we know the upper bounds for the alternative policy instruments, we consider policies where several policy instruments are implemented simultaneously. The purpose is that each externality is targeted using an appropriate policy instrument; some of the policy instruments presented above are substitutes and some complement each other. For example, a corporate tax is a common form of taxation internationally. Therefore, we include a baseline corporate tax (of 20\%) in all policy packages in the following simulations. Otherwise, we build unique policy packages with alternative combinations of resource and environmental policy instruments.

We start with choosing between resource policy instruments: an ad valorem tax, a royalty and an excess corporate income tax imposed on the mining industry. As these instruments are alternatives to each other, we first choose a level for one and calculate the government revenue it generates. Thereafter, we set the levels of the other two instruments such that they generate the same amount of government revenue as the first.

An ad valorem tax is widely used as a resource tax. The level of the tax is motivated on various grounds, and different rates may be applied to different metals. ${ }^{18}$ Here, we fix the ad valorem tax at $5 \%$ in our simulations. Basically, this is a rent that the government claims for the use of its asset, or a common property nonrenewable resource stock. Accordingly, the size of the royalty and excess

\footnotetext{
${ }^{18}$ There is a large theoretical literature in economics on optimal taxation of non-renewable resources (see, e.g., Boadway and Keen 2015; Gaudet and Lasserre 2015; Lund 2009) but implementation of taxes or royalties in practice is based on various policy considerations and compromises (see, e.g., Hogan 2008, Guj 2012, Mineral Royalty Rate Analysis 2015).
} 
corporate tax rate are chosen to match the same revenue flow to the government as in the case of the ad valorem tax of $5 \%$ over time in the simulations.

Regarding the level of the environmental policy instruments, we proceed in the reverse order and take the amount of revenue to be collected by the government as the compensation required for environmental damages caused during the lifetime of a mine. Four alternative environmental policy instruments are applied to compensate for environmental damages. We set the amounts of both the fine and surety bond at USD 200 million, which corresponds to the cost of closing a mine prematurely in case of an environmental accident. Accordingly, the Pigou tax per effluent is set at a level that generates the same amount of money for the government over the years the mine operates. In theory, an optimally set Pigou tax reflects the marginal damage of an additional unit of polluting effluent. Hence, we implicitly assume that the marginal damage of pollution is constant over time.

The up-front liability payment differs in nature from the other three instruments. As it is a nonrefundable payment, we interpret it here as collective compensation for an environmental accident that may occur in any mine in the industry. Therefore, we set the payment at USD 20 million, which is only one-tenth of the surety bond or fine. This is as if there were only nine other mines in the industry subject to a similar up-front payment collectively. Clearly, the number of the firms in the industry that are collectively liable for mining accidents affects the level of the payment that each mining firm must pay to a liability fund; that is, the size of the payment is subject to the size of the industry. However, in the simulations, we can see how a non-refundable payment impacts the firm's profits and government revenue and how its magnitude relates to the probability of an accident.

The simulation results for the different policy packages in net present value terms over the lifecycle of the mining project are reported in Table $\mathrm{C} 1$ in Appendix C. In all simulations, low operating costs are assumed (Low-Cost as in Tables 3 and 4). First, we find that when we use an ad valorem tax rate of $5 \%$, the other two resource policy instruments generate roughly the same government revenue at the Target 1 production level when the royalty is USD 1.6 per ton of ore extracted, or alternatively, the excess corporate tax rate is $14 \%$ (Table C1). If production increases to Target 2, then a slightly lower excess corporate tax rate of $13 \%$ can be applied to reach the same tax revenue as the ad valorem tax of $5 \%$ yields. Moreover, the size of the royalty and the corporate tax rate remain the same even if the probability of an accident at the mine increases to $1 / 30 .{ }^{19}$

\footnotetext{
${ }^{19}$ In addition to the results reported in Table $\mathrm{C} 1$, we have run several simulations including those at alternative production target levels, Baseline and Target 2, and with an alternative probability of an accident in mine, 1/30. All these results are available from the authors upon request.
} 
Each of the above resource policy instruments is then combined with one of the environmental policy instruments, and the results for production level Target 1 can be seen column by column in Table C1. Comparison of the instruments shows that the excess corporate tax rate (recall that a basic corporate tax rate of $20 \%$ is included in all policy packages) generates the highest profits for the firm independent of the environmental policy instrument it is combined with. This means that also the probability of net present value of the firm being positive is highest when excess corporate tax is applied as a resource policy instrument (the lowest row in Table $\mathrm{C} 1$ ). The difference compared to the other two resource policy instruments, the ad valorem tax and royalty, becomes slightly more pronounced when production increases to the Target 2 level: The range of NPV $>0$ is $75-81 \%$ for an excess corporate tax rate of $13 \%$. Of course, this is the most favorable policy instrument for the mining firm as the firm is taxed only when it makes a profit.

As regards the comparison of environmental policy instruments, recall that the environmental damage to be compensated by the mining firm to society was fixed at USD 200 million. Therefore, the fine paid only when an accident occurs with a probability of $1 / 100$ generates the lowest revenues for the government (Table C1). However, if the probability of an accident increases to $1 / 30$, the up-front liability payment becomes the lowest source of income to the government and generates the lowest compensation for environmental damages. This is because the factual fine payment is always determined by the probability of an accident, but a fixed liability payment does not change when the probability increases. Finally, the fixed environmental damage during the lifetime of the mine is consistent with different marginal damages by production level, and this is seen in the Pigou tax rate. The Pigou tax is USD 1,000 per ton of effluent at production level Target 1, but only USD 600 at production level Target 2.

All in all, the basic lesson from the simulations is that it is possible to find a reasonable level for a policy instrument by first determining the government revenues to be collected using the instrument. What is an appropriate rent from a nonrenewable resource stock is, of course, a policy decision per se, but given the revenue to be collected, simulations are helpful in determining the levels for alternative instruments. The same applies to simulating the levels of environmental policy instruments when the goal is to generate a sum of money for the government that compensates it for environmental damages caused by a mine.

The results on the government revenues and firm profits are presented in summary terms as average net present values calculated over the lifetime of the firm in Table C1. It is useful to illustrate the impacts of policy packages such that the distributions of summary statistics from the simulations are 
also shown. In doing so, the distributions affected by uncertain elements of the modelling are more clearly seen for each policy package. Figure 4 shows the net present values of the mine and government revenues from the 1,000 simulations when an ad valorem tax of 5\%, a basic corporate tax of $20 \%$ and an up-front liability payment of USD 20 million are implemented at production level Target 1 (corresponding to the third column in Table C1 in Appendix C). The figure shows that both distributions are asymmetric with heavy right tails that result from positive random shocks. The upper graph of the figure shows that the average net-of-tax profits for the open mine $\left(N P V_{O P E N}=\right.$ $U S D$ 936M) is highly positive, and the likelihood that the NPV >0 is about $73 \%$. The lower panel shows the average NPV that the government collects $\left(N P V_{G O V}=U S D 352 M\right)$.

For illustrative purposes, we have included in Appendix D an additional figure where distributions of the net present value of the firm and government revenues are depicted from another set of 1,000 simulations. In Figure D1, the policy package is different from that in Figure 4 in that the up-front liability payment is replaced with a Pigou tax of USD 1,000 per ton of effluent. Now the distribution of the government revenue moves to the right, whereas the net-of-tax profits move to the left. This is consistent with our findings above on the corresponding average net present values reported in Table C1. 


\section{Net Present Value of the Mine}

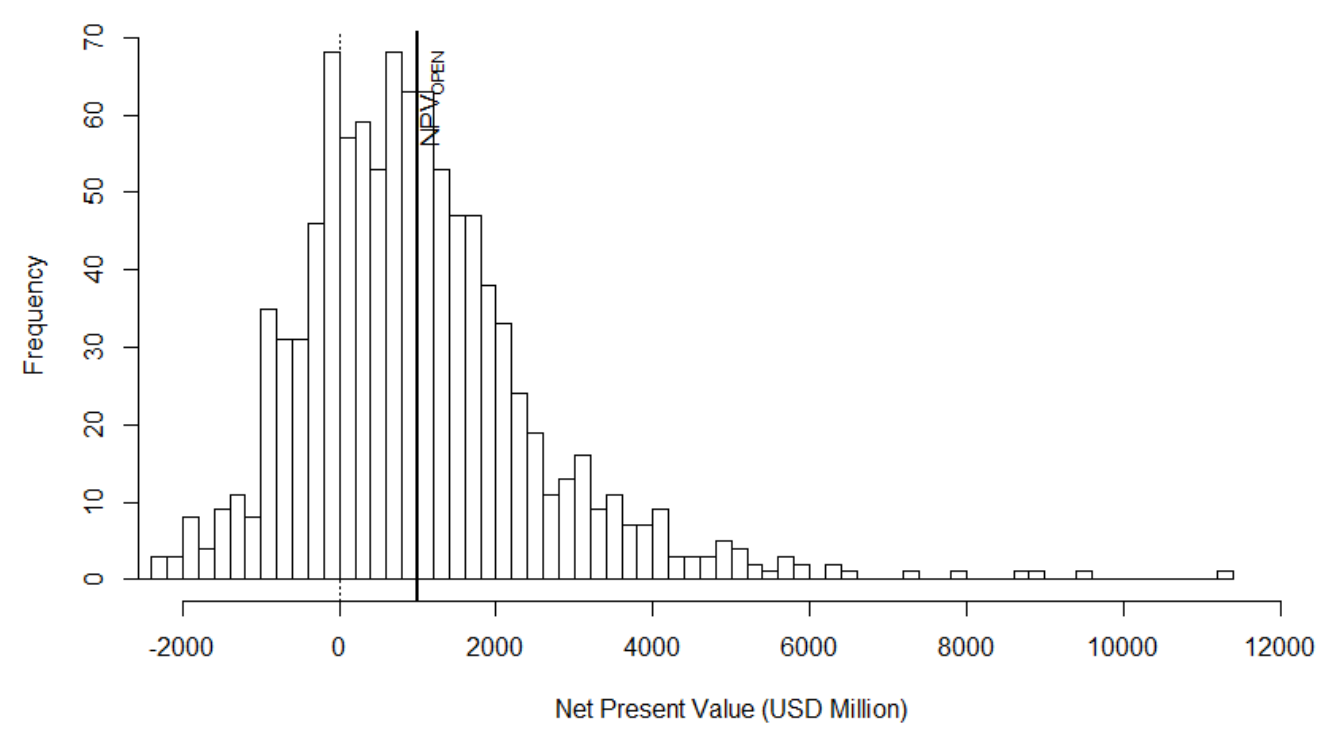

Government Collects, in Net Present Value

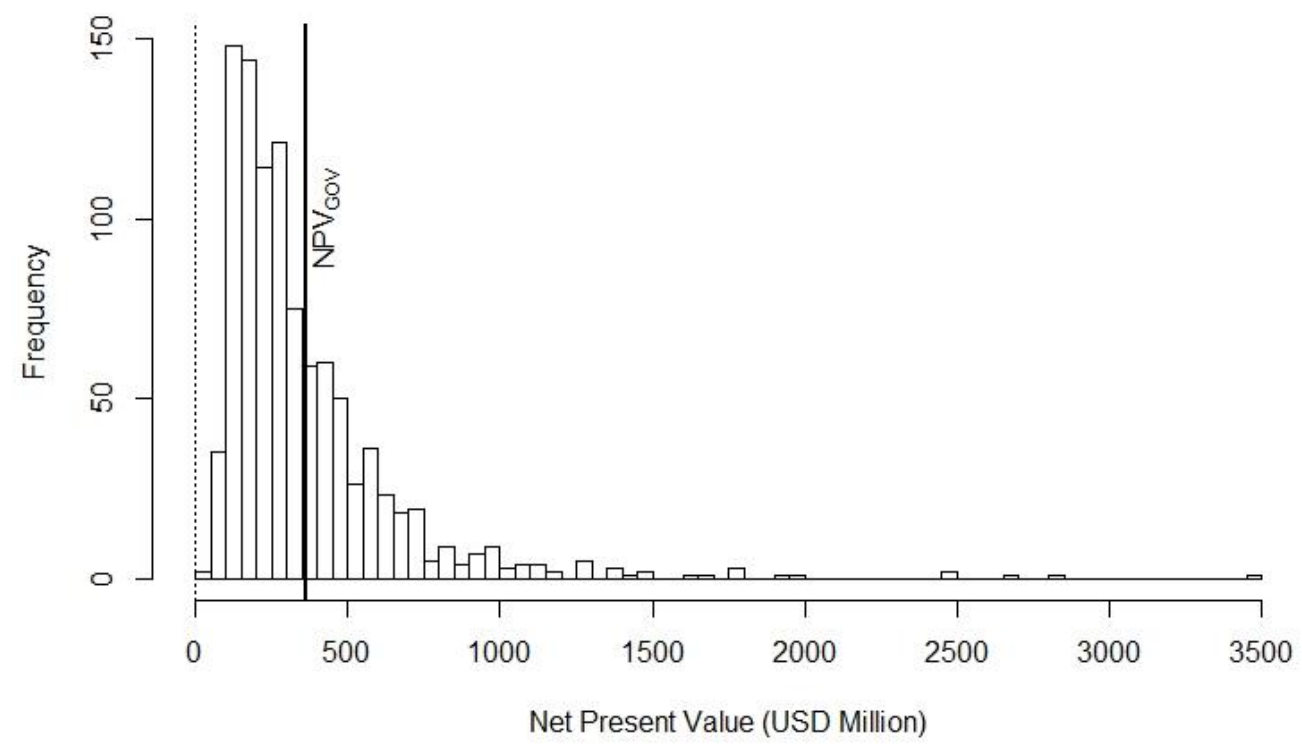

Figure 4. Simulated net present values of firm profits and government revenues with ad valorem tax $5 \%$, corporate tax $20 \%$ and up-front payment USD 20 million (production level target 1)

As a final comparison of policy instruments based on simulations, we look at how the uncertainties affect the expected revenues from the three resource policy instruments and a simultaneous environmental policy instrument, the Pigou tax, in Figure 5. 


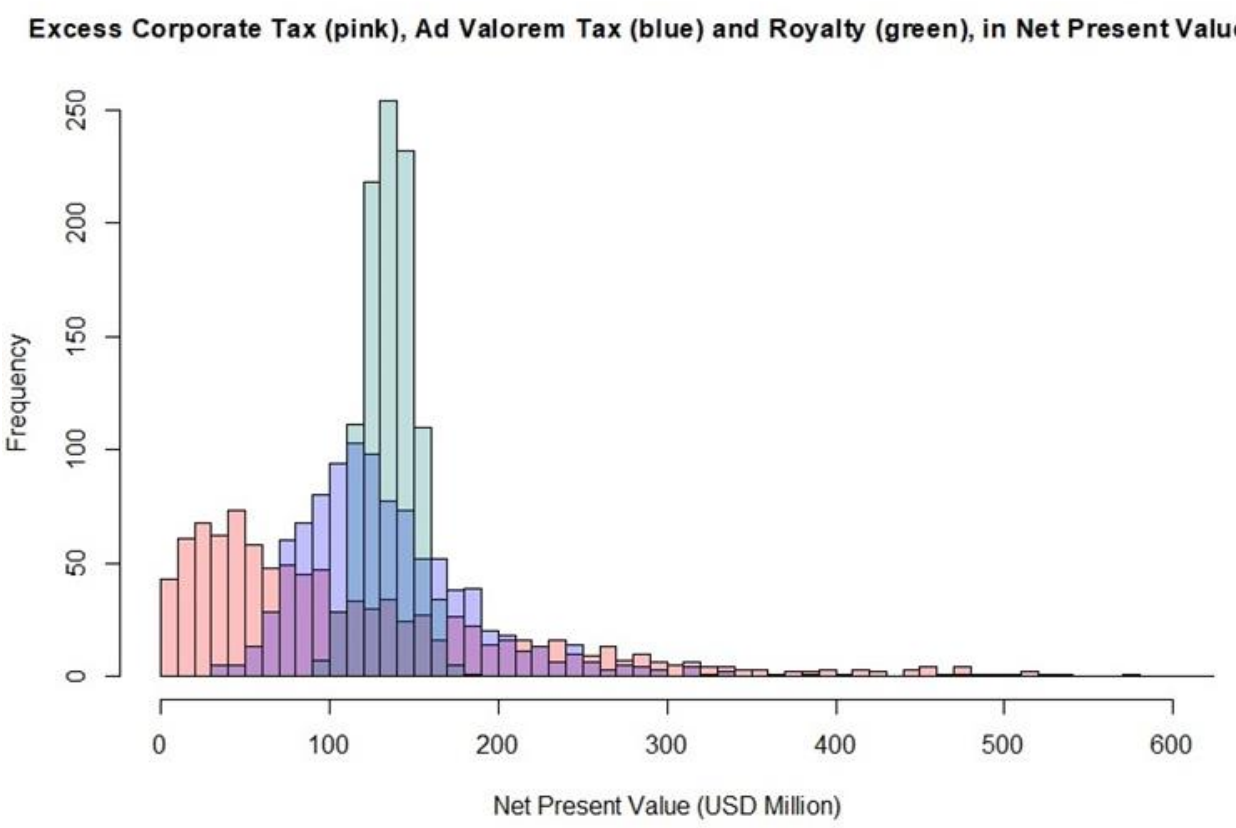

Pigou Tax, in Net Present Value

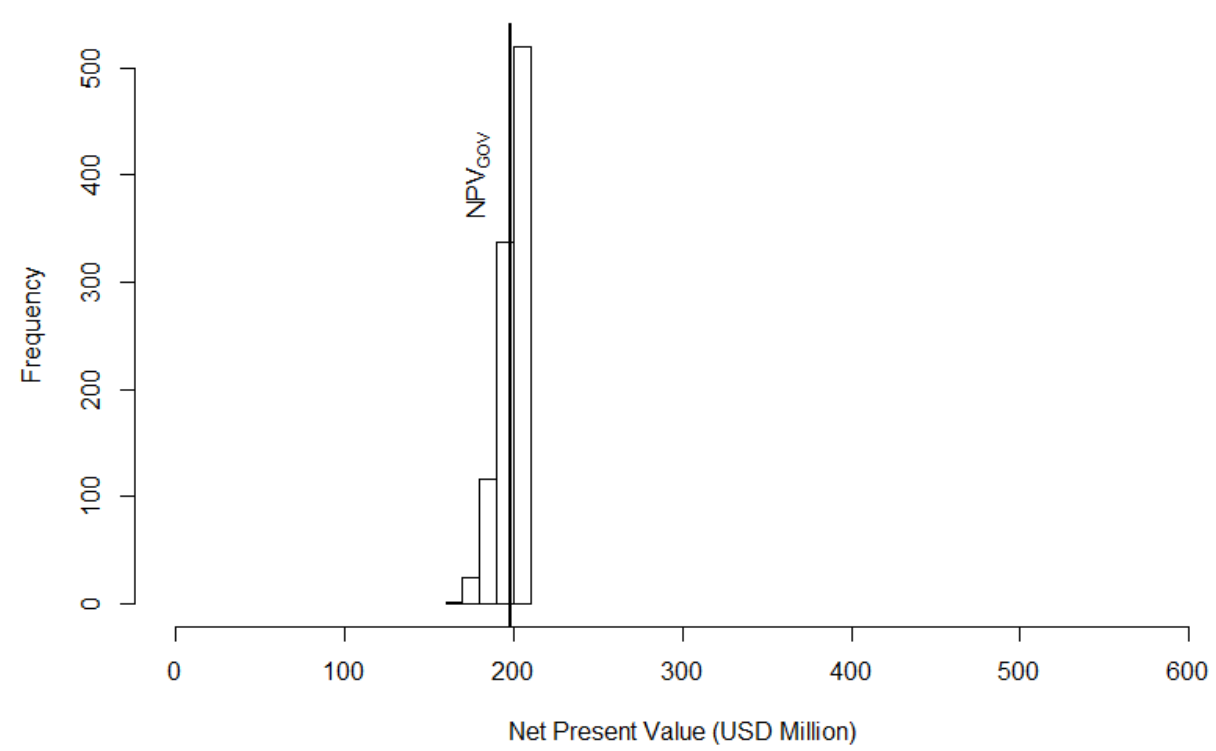

Figure 5. Simulated net present values of government revenues by policy instrument: excess corporate tax 14\% (upper figure, pink), ad valorem tax 5\% (upper figure, blue), royalty of USD 1.6 per ton of ore (upper figure, green) and Pigou tax of USD 1,000 per ton of effluent (lower figure). Baseline corporate tax $20 \%$ and production level target 1 .

Recall that the uncertainties of price, technology and environmental impacts affect the mining operations differently, as reflected in distributions of revenues from alternative resource taxes. In Figure 5, the ad valorem tax $\left(\tau^{A D}=0.05\right)$, royalty $(\lambda=\$ 1.6$ per ton of ore) and excess corporate tax $\left(\tau^{\text {CORP }}=0.14\right)$ are shown in the upper panel and a Pigou tax of USD 1,000 per ton of effluent is 
shown in the lower panel (these correspond to the results of Table $\mathrm{C} 1$ and Target 1 production level in Appendix C).

The spread of the excess corporate tax revenues is widest because both price and quantity uncertainty affects the profits. The expected revenues from the royalty are less dispersed as only the uncertainty regarding the extracted amount of ore affects the outcome. The distribution of expected revenues from the ad valorem tax lies somewhere in between the other two instruments. Only price uncertainty matters for the taxation of the value of output. However, compared to the resource tax revenues, there is very modest uncertainty about Pigou tax revenues (lower panel Figure 5), as they are related to the extracted amounts of ore and the corresponding effluents generated as a by-product. This explains why the revenues from royalty payments and Pigou taxes on effluents are similarly distributed. If our modelling of different types of uncertainties are generally true for the mining industry, then it is possible to conclude that royalties may also capture the social costs of environmental impacts as a policy instrument.

\section{Conclusions}

We have considered a multi-metal mine operating under uncertainty related to 1) world market prices of metals, 2) production technology and 3) environmental impacts. We have analyzed whether the mine should remain open or be closed when closing is costly due, for example, to land rehabilitation and reclamation at the mining site. Given our parameter values based on the prototype mine, metal markets and experiences with an unconventional (heap leaching) technology, we have shown that metal (nickel and zinc) extraction may turn out to be unprofitable. Only when operating costs are rather low or metal prices are initially higher than the historical average prices does it pay off to continue mining activities. However, when the premature closing costs are high, it may be worthwhile to keep an unprofitable mine operating, because continuing mining activities may result in a smaller overall loss in the long run than closing the mine immediately. An important consideration is to scale the operations and production such that maximum losses are avoided.

Furthermore, we have investigated alternative government resource policy interventions by introducing an ad valorem tax on output, a mining-industry-specific excess corporate tax rate and a royalty on the amount of ore extracted. Comparison of the instruments show that an excess corporate tax rate on mining (i.e., in addition to a normal corporate tax rate) generates the highest profits for the firm. The difference compared to the other two resource policy instruments, an ad valorem tax and royalty, becomes slightly more pronounced when production increases. Of course, this is the most 
favorable policy instrument for the mining firm as it is taxed only when it makes a profit. However, as the corporate income tax rate is subject to international tax competition, it may not be the most favorable instrument from the point of view of the government or policy makers.

What is an appropriate rent from a nonrenewable resource stock is, of course, a political decision per se, but given the revenue to be collected for the government, our results are helpful in determining the levels for alternative resource policy instruments. On the other hand, when the goal is to generate a sum of money that compensates the government for the environmental damages caused by a mine, the revenue target can be used as a constraint when simulating the levels of alternative environmental policy instruments, these being a Pigou tax on effluents, fines for environmental accidents, a mandatory up-front payment to an environmental liability fund and a financial surety to cover closure and reclamation costs.

Most interestingly, the Pigou tax generates the highest expected compensation in terms of net present value. In addition, as it is proportional to the amount of the resource extracted, the revenue is similarly distributed to that from the royalty. In contrast, the fine paid only when an accident occurs with a low probability generates the lowest revenues for the government. However, if the probability of a severe accident increases, the up-front liability payment becomes the lowest form of compensation to the government for the environmental damage. This change occurs because a fine is always determined by the probability of an accident, but a fixed liability payment does not increase even when the probability of an accident does. However, the most serious concern with ex post fines is that firms can declare bankruptcy and escape their liabilities. A surety bond can achieve social efficiency.

Adopting a new technology to bring nonrenewable resources with relatively poor ore content into production is challenging and may turn out to be unprofitable. Because of the potentially extensive social costs generated by mining, governments should carefully consider the soundness of policies that support mining operations for reasons related solely to regional development or employment. In situ value and externalities play an important role from a social point of view and they should be considered in policy design globally as well. Climate policy - with a focus on greenhouse gases should be aligned with resource policies to avoid the problem that regulating one pollutant induces technological change that may transform pollution to another form of waste that is not regulated. When considering fiscal reforms and intervention through resource and environmental policy instruments, holistic assessments should be carried out making use of mine fiscal models (Otto 2018). This is particularly important for resource-rich, developing economies building up institutions for taxation and environmental regulation. 


\section{References}

Addison, T. and Roe, A. 2018. Extractive Industries: The Management of Resources as a Driver of Sustainable Development. A study prepared by the United Nations University World Institute for Development Economics Research (UNU-WIDER). Oxford Scholarship Online.

Arguedas, C. 2005. Bargaining in environmental regulation revisited. Journal of Environmental Economics and Management 50(2): 422-433.

Ayres, R., and Kneese, A. 1969. Production, consumption and externalities. American Economic Review 9: 282-297.

Baumeister, C. and Kilian, L. 2016. Forty Years of Oil Price Fluctuations: Why the Price of Oil May Still Surprise Us. Journal of Economic Perspectives 30(1): 139-60.

Boadway, R. and Keen, M. 2015. Rent Taxes and Royalties in Designing Fiscal Regimes for NonRenewable Resources. In D. Layton and R. Halvorsen (eds) Handbook on the Economics of Natural Resources, Edward Elgar.

Boomhower, J. 2019. Drilling Like There's No Tomorrow: Bankruptcy, Insurance, and Environmental Risk. American Economic Review 109: 391-426.

Bowell, R. J. 2004. A review of sulphate removal options for mine waters. In A.P. Jarvis, B.A. Dudgeon and P.L.Younger (eds): Mine water 2004 - Proceedings International Mine Water Association Symposium 2. Newcastle upon Tyne (University of Newcastle).

Brennan, M.J. and Schwartz, E.J. 1985. Evaluating natural resource investments. Journal of Business 58: 135-157.

Chakarvarty, U. 2018. Renewable Energy Material Supply Implications. IAEE Energy Forum, First Quarter 2018: 37-39.

Chevallier, J. and Ielpo, F. 2014. Twenty years of jumps in commodity markets, International Review of Applied Economics 28: 64-82.

COM 2020. A new Circular Economy Action Plan for a Cleaner and More Competitive Europe. Communication from the Commission to the European Parliament, the Council, the European Economic and Social Committee and the Committee of the Regions COM/2020/98 final.

Conde, M. 2017. Resistance to Mining. A review. Ecological Economics 132: 80-90.

Cust, J. and Poelhekke, S. 2015. The Local Economic Impacts of Natural Resource Extraction. Annual Review of Resource Economics 7: 251-268.

Daniel, P., Keen, M. and McPherson, C. 2010. The taxation of petroleum and minerals: principles, problems and practice. Routledge, New York.

Dasgupta, P.S. and Heal, G.M. 1979. Economic Theory and Exhaustible Resources. Cambridge Economic Handbooks. University Press Oxford. 
Devereux, Michael P. and Simon Loretz (2013): What do We Know about Corporate Tax Competition. National Tax Journal 66(3): 745-774.

Dharmapala, D. 2014. What Do We Know About Base Erosion and Profit Shifting? A Review of the Empirical Literature. Fiscal Studies 35: 421-448.

Dixit, A. and Pindyck, R.S. 1994. Investment Under Uncertainty. Princeton University Press, Princeton.

Farrow, S. 1985. Testing the Efficiency of Extraction from a Stock Resource. Journal of Political Economy 93: 452-487.

Farzin, Y.H. 1996. Optimal pricing of environmental and natural resource use with stock externalities. Journal of Public Economics 62: 31-57.

Ferraro, D. and Peretto, P.F. 2017. Commodity Prices and Growth. The Economic Journal 128: $3242-$ 3265.

Finér, L. and Ylönen, M. 2017. Tax-driven wealth chains: A multiple case study of tax avoidance in the Finnish mining sector. Critical Perspectives on Accounting 48: 53-81.

Gaudet, G. and Lasserre, P. 2015. The Taxation of Non-Renewable Natural Resources. In D. Layton and R. Halvorsen (eds) Handbook on the Economics of Natural Resources, Edward Elgar.

Guj, P. 2012. Mineral royalties and other mining-specific taxes. Mining for Development: Guide to Australian Practice, International Mining for Development Centre, Western Australia. http://www.eisourcebook.org/cms/March_2013/Mineral\%20royalties\%20\&\%20other\%20miningspecific\%20taxes.pdf [Accessed 30 January, 2020]

Guyonnet, D. and Touze-Foltz, N. 2014. Assessing the risk of leakage from heap leach pads used in mining operations. The Extractive Industries and Society 1: 96-103.

Halinen, A.-K. 2015. Heap Bioleaching of Low-Grade Multimetal Sulphicid Ore in Boreal Conditions, Thesis for the degree of Doctor of Science in Technology, Tampere University of Technology, Publication 1347.

Hartwick, J. M. 1977. Intergenerational Equity and the Investment of Rents from Exhaustible Resources. American Economic Review 67: 972-74.

Heckemeyer, J. H. and Overesch, M. 2017. Multinational' Profit Response to Tax Differentials: Effect Size and Shifting Channels. Canadian Journal of Economics 50(4): 965-994

Hogan, L. 2008. International minerals taxation: experiences and issues. ABARE Conference paper 08.11

Hotelling, H. 1931. The Economics of Exhaustible Resources. The Journal of Political Economy, 39(2): 137-175.

Huhtala, A. 1999. Optimizing production technology choices: Conventional production vs. recycling. Resource and Energy Economics 21: 1-18. 
Insley, M. C. 2017. Resource extraction with a carbon tax and regime switching prices: Exercising your options. Energy Economics 67: 1-16.

Jacks, D.S. and Stuermer, M. 2020. What drives commodity price booms and busts? Energy Economics 85, available online.

Jenkins, H. and Yakovleva, N., 2006. Corporate social responsibility in the mining industry: Exploring trends in social and environmental disclosure. Journal of Cleaner Production 14: 271-284.

Jones, C.I. 2016. The facts of economic growth. In Handbook of Macroeconomics, vol. 2A. Elsevier.

Kappes,. D.W. 2002. Precious Metal Heap Leach Design and Practice. Mimeo. http://www.oremax.com/pdfs/resources/precious_metal_heap_leach_design_and_practice.pdf [Accessed 26 January 2020].

Kellogg, R. 2014. The Effect of Uncertainty on Investment: Evidence from Texas Oil Drilling. American Economic Review 104: 1698-1734.

Kemp, M.C. and Long, N.V. 1980. Toward a more general theory of the mining firm. In M.C. Kemp and N.V. Long (eds.) Exhaustible resources, optimality, and trade. North-Holland, Amsterdam.

KPMG 2019. Corporate tax rates table (27 August 2019)

Krautkraemer, J.A. 1998. Nonrenewable Resource Scarcity. Journal of Economic Literature, 36(4): 2065-2107.

Kyle, J. 2010. Nickel laterite processing technologies - where to next? In: ALTA 2010 Nickel/Cobalt/Copper Conference, 24 - 27 May, Perth, Western Australia.

Lappi, P. 2020. A model of optimal extraction and site reclamation. Resource and Energy Economics forthcoming.

Lund, D. 1993. The lognormal diffusion is hardly an equilibrium price process for exhaustible resources. Journal of Environmental Economics and Management 25: 235-241.

Lund, D. 2009. Rent Taxation for Non-Renewable Resources. Annual Review of Resource Economics $1: 287-307$.

Mason, C. F. 2001. Nonrenewable Resources with Switching Costs. Journal of Environmental Economics and Management 42: 65-81.

Mason, C. F. 2012. On equilibrium in resource markets with scale economies and stochastic prices. Journal of Environmental Economics and Management 64: 288-300.

Meays, C. and Nordin, R. 2013. Ambient water quality guidelines for sulphate. Technical Appendix. Ministry of Environment, Province of British Columbia.

Mine Closure Handbook 2008. Heikkinen, P.M., Noras, P. and Salminen, R. (eds.) Miscellaneous publications 74, Geological Survey of Finland, Espoo.

Mineral Royalty Rate Analysis 2015. Final Report. Department of State Development, Department of Mines and Petroleum, Government of Western Australia. 
MIT 2016. Environmental risks of mining. The future of strategic natural resources. http://web.mit.edu/12.000/www/m2016/finalwebsite/problems/mining.html [Accessed January 26, 2019.]

Mudd, G.M. and Jowitt, S.M. 2014. A Detailed Assessment of Global Nickel Resource Trends and Endowments. Economic Geology 109: 1813-1841.

Muehlenbachs, L. 2015. A Dynamic Model of Cleanup: Estimating Sunk Costs in Oil and Gas Production. International Economic Review 56: 155-185.

OECD 2015. Towards Green Growth? Tracking Progress, OECD Green Growth Studies, OECD Publishing, Paris.

Otto, J.M. 2018. The Taxation of Extractive Industries. In T. Addison and A. Roe (eds.) Extractive Industries: The Management of Resources as a Driver of Sustainable Development. A study prepared by the United Nations University World Institute for Development Economics Research (UNUWIDER). Oxford Scholarship Online.

Pigou, A.C. 1920. The Economics of Welfare. Macmillan \& Co.

van der Ploeg, F. 2011. Natural Resources: Curse or Blessing? Journal of Economic Literature 492: $366-42$.

van der Ploeg, F. and Venables, A.J. 2018. Extractive Revenues and Government Spending. In T. Addison and A. Roe (eds.) Extractive Industries: The Management of Resources as a Driver of Sustainable Development. A study prepared by the United Nations University World Institute for Development Economics Research (UNU-WIDER). Oxford Scholarship Online.

Prior, T., Giurcoa, D., Mudd, G., Mason, L., and Behrisch, J. 2012. Resource depletion, peak minerals and the implications for sustainable resource management Global Environmental Change 22: 577587.

Punkkinen, H., Räsänen, L., Mroueh, U.-M., Korkealaakso, J., Luoma, S., Kaipainen, T., Backnäs, S., Turunen, K., Hentinen, K., Pasanen, A., Kauppi, S., Vehviläinen, B. and Krogerus, K. 2016. Guidelines for mine water management, VTT Technology 266.

Reichardt, C. 2008. Heap Leaching and the Water Environment - Does Low Cost Recovery Come at a High Environmental Cost? Mimeo.

https://www.imwa.info/docs/imwa_2008/IMWA2008_008_Reichardt.pdf [Accessed 30 January, 2020].

Roan, P.F. and Martin, W.E. 1996. Optimal production and reclamation at a mine site with an ecosystem constraint. Journal of Environmental Economics and Management 30: 186-198.

Sachs, J.D. and Warner, A.M. 2001. The Curse of Natural Resources, European Economic Review 45: 827-3.

Sharp, T. 2012. Managing sulfate impacts on water quality. SRK Consulting's International Newsletter, Issue 46.

Shavell, S. 2007. Liability for Accidents. In A.M. Polinsky and S. Shavell (eds.) Handbook of Law and Economics, Volume 1, Elsevier B.V. 
USGS 2019. Mineral commodity summaries 2019: U.S. Geological Survey, 200p., https://pubs.er.usgs.gov/publication/70202434 [Accessed 30 January 2020]

Veijalainen, N. 2012. Estimation of climate change impacts on hydrology and floods in Finland. School of Engineering, Aalto University publication series Doctoral Dissertations 55/2012.

Veijalainen, N., Jakkila, J., Nurmi, T., Vehviläinen, B., Marttunen, M., and Aaltonen, J. 2012. Finland's water resources and climate change - Effects and adaptation, final report of the WaterAdapt -project (in Finnish with English summary). The Finnish Environment 16/2012. https://helda.helsinki.fi/handle/10138/38789 [Accessed 26 February 2020]

Yang, P., and Davis, G.A. 2018. Non-renewable resource extraction under financial incentives to reduce and reverse stock pollution. Journal of Environmental Economics and Management 92: 282299.

Yin, H., Pfaff, A., and Kunreuther, H. 2011. Can Environmental Insurance Succeed Where Other Strategies Fail? The Case of Underground Storage Tanks. Risk Analysis 31: 12-24.

Warhurst, A. and Mitchell, P., 2000. Corporate social responsibility and the case of Summitville mine. Resources Policy 26: 91-102.

White, B. 2015. Do control rights determine the optimal extension of liabil ity to investors? The case of environmental policy for mines. Journal of Regulatory Economics 48: 26-52.

World Bank 2017. The growing role of minerals and metals for a low-carbon future. http://documents.worldbank.org/curated/en/207371500386458722/pdf/117581-WP-P159838PUBLIC-ClimateSmartMiningJuly.pdf [Accessed 6 January 2020]

\section{Data Sources}

Finnish Environment Institute 2013a. Environmental information on mining projects: background information on mining legislation and environmental monitoring in certain mines (in Finnish with English summary) Reports of the Finnish Environment Institute 10/2013.

Finnish Environment Institute 2013b. Assessment of the potential impacts on water environment caused by the gypsum pond leakage at the Talvivaara mine (in Finnish with English summary) Reports of the Finnish Environment Institute 11/2013.

Geological Survey of Finland 2017. Discharge waters from Terrafame OY in Nuasjärvi Sotkamo (Terrafame Oy:n purkuvesien leviäminen ja käyttäytyminen Sotkamon Nuasjärvellä, In Finnish). Memorandum, GTK/69/03.01/2017. Espoo.

International Nickel Study Group 2017. About nickel [online] Available from: https://insg.org/index.php/about-nickel/what-is-nickel/ [Accessed 27 January 2020]

Mudd, G.M. 2010. Global Trends and Environmental Issues in Nickel Mining: Sulfides versus Laterites. Ore Geology Reviews 38: 9-26.

Mudd, G.M., Jowitt, S.M. and Werner, T.T. 2017. The world's lead-zinc mineral resources: Scarcity, data, issues and opportunities. Ore Geology Reviews 80: 1160-1190. 
Oxley, A. and Barcza, N. 2013. Hydro-pyro integration in the processing of nickel laterites. Minerals Engineering 54: 2-13.

Papp, J.F, Bray, E.L., Edelstein, D.L., Fenton, M.D., Guberman, D.E., Hedrick, J.B., Jorgenson, J.D., Kuck, P.H., Shedd, K.B. and Tolcin, A.C. 2008. Factors that influence the price of Al, Cd, $\mathrm{Co}, \mathrm{Cu}, \mathrm{Fe}, \mathrm{Ni}, \mathrm{Pb}$, Rare Earth Elements, and Zn. Open-File Report 2008-1356, U.S. Department of the Interior, U.S. Geological Survey.

Ramboll 2015, 2016, 2017. Annual monitoring reports of water discharges from the Terrafame mine. (reports in Finnish, Terrafamen vesipäästöjen tarkkailuraportit vuosilta 2015-2017)

Safety Investigation Authority 2014. Environmental accident at the Talvivaara mine in November 2012, Investigation Report, Tutkintaselostus 5/2014 (in Finnish with English summary), Helsinki.

Talvivaara Annual Reports 2008-2012

Trujillo, J.Y., Cisternas, L.A., Gálvez, E.D. and Mellado, M.E. 2014. Optimal design and planning of heap leaching process. Application to copper oxide leaching. Chemical Engineering Research and Design 92: 308-317.

Wedderburn, B. 2010. Nickel Heap Leaching Study. Presentation at the International Nickel Study Group (INSG) Environmental \& Economics Session, 27 $7^{\text {th }}$ April 2010.

The World Bank 2020: Commodity Markets, Annual Prices

https://www.worldbank.org/en/research/commodity-markets [Accessed 6 January 2020] 
Our modelling of the nickel price changes takes place in two steps. In the first step, we focus on the two years when the yearly price changes were exceptionally high. According to the data, each of these takes place with a probability of $\frac{1}{57}$. To model the occurrence of the first price increase of $166 \%$, we take a random draw for each of the 29 years (following the first year) when the mine is active from a 0/1-distribution, where the value 1 occurs with a probability of $\frac{1}{57}{ }^{20}$ The value of 1 then implies a 166 $\%$ price increase for that year. Following the random draws for this first event, we take the corresponding 29 random draws for the other exceptional price increase of $60 \%$ and combine these draws with the random draws from the first event. ${ }^{21}$ We also take into account the observed price decreases following the exceptionally high price increases. This is done by forcing a corresponding opposite price change to follow each extreme event. A $166 \%$ price increase in year $t$ is followed by a $62 \%$ price decrease in year $t+1$, and a $60 \%$ price increase is followed by a $38 \%$ price decrease. $^{22}$

In the second step, we consider the years when there are no extreme price changes. ${ }^{23}$ For those years, we use two different sets of price changes, those that took place before 1988 (in Figure 1 those that are to the left of that year; "pre-switch observations") and those occurring after it (excluding the observation for the year 2006; "post-switch observations"). For the 29 years which pass before the first extreme price change, we draw price changes from the set of pre-switch observations (with replacement). For the remaining years the observations are drawn from the post-switch observations (also with replacement). If no extreme changes at all occur in the random draw, each of the 29 price changes is drawn from the pre-switch observations.

The modelling of zinc prices is conducted in a single step, because, in contrast to nickel prices, the volatility of zinc prices does not change after the extreme cases. However, we do take into account the fact that the high price increases seem to be followed by a corresponding decrease in close years.

\footnotetext{
${ }^{20}$ The mine is assumed to be active for 30 years. For the first year, the price is chosen in the benchmark case to be USD $10,000 /$ ton. For the other 29 years, the prices are determined by the consequent price changes in each year.

${ }^{21} \mathrm{We}$ treat the first and the second extreme events as i.i.d., yet allow there to be at most one of these exceptional changes in a year. If both cases are randomly drawn to occur for the same year, the first one is chosen.

${ }^{22}$ Note that because we consider T years, there is no opposite price change if an extreme event occurs in year T.

${ }^{23}$ There are typically 0 or only few extreme events in a set of 29 random draws. Therefore, most of the random draws underlying the simulations come from the second step.
} 
For zinc there are three price changes exceeding 50\%. ${ }^{24}$ In our simulations, the occurrence of each of these is followed by a corresponding opposite price change in the following year.

Figure A1 illustrates one random draw for the metal price changes over 29 years. The left-hand graph depicts changes in the price of nickel and the right-hand graph changes in the price of zinc. In the draw for the changes in the price of nickel, there occurs a single extreme increase in price of $166 \%$ in year 11 . This event is followed by a compensatory price decrease of $62 \%$ in year 12 . Therefore, up until year 10 all the price changes are drawn from the set of pre-switch observations. The price changes from period 13 onwards are drawn from the set of post-switch observations. The yearly price levels are then constructed using the initial price for year $t=1$ together with the simulated yearly price changes. For the changes in the price of zinc there are two extreme events (in years 9 and 21). These are followed by compensatory price decreases in the next year.
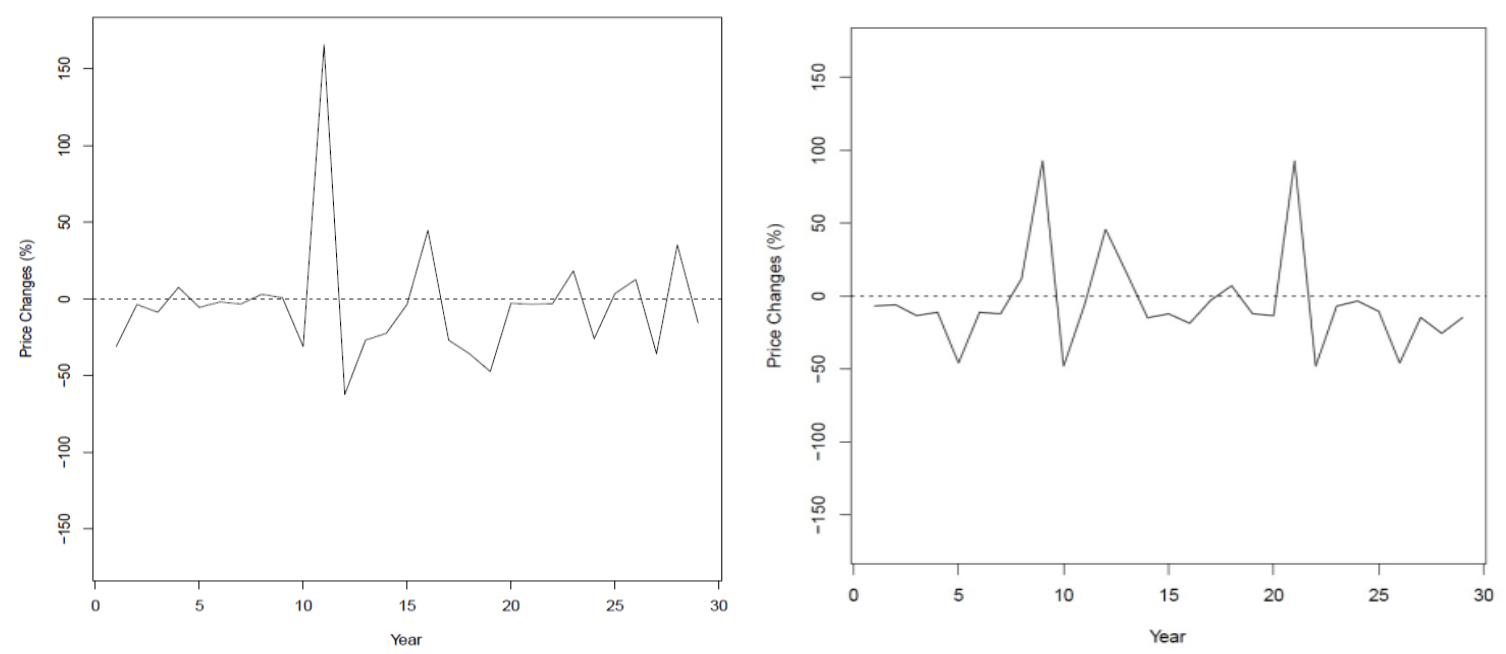

Figure A1. A random draw for nickel (left) and zinc (right) price evolutions

${ }^{24} 52.2 \%$ in $1964,93.0 \%$ in 1973 and $131.3 \%$ in 2006. These are compensated by price decreases of $34.31 \%, 48.18 \%$ and $56.75 \%$ respectively. 


\section{Appendix B}

\section{Modelling the extraction of natural resources with environmental effects}

The social costs of a mining firm are captured by shadow prices of resource and environmental constraints. As the resource industry is assumed to be composed of identical price-taking firms, we normalize the number of firms to one and consider the behavior of the representative firm to be that of the industry. For a given price process, $p^{t}$, quantity of extraction, $q^{t}$, at each time period $t=1,2, \ldots, T$, and costs of extraction, $c\left(q^{t}\right)$, depending on the amount extracted, the social planner's objective is to maximize the expected flow of revenues net of extraction costs and discounted over time by a discount factor $\rho^{t}$

$$
E \sum_{t=1}^{T} \rho^{t}\left[p^{t} q^{t}-c\left(q^{t}\right)\right]
$$

subject to the dynamics of the non-renewable resource stock, $R^{t}$

$$
R^{t+1}=R^{t}-q^{t}
$$

and the accumulation of the waste stock, $W^{t}$

$$
W^{t+1}=W^{t}+e^{t} q^{t}
$$

The waste stock is increased by the flow of residuals, and the magnitude of the environmentally harmful impact of residuals, $e^{t}$, is proportional to the quantities extracted. By replacing the stochastic variables with their expected values and denoting them by $\tilde{p}, \tilde{q}$, and $\tilde{e}$, the current value Hamiltonian for the problem becomes $H=\tilde{p}^{t} \tilde{q}^{t}-c\left(\tilde{q}^{t}\right)-\rho \lambda^{t+1} \tilde{q}^{t}+\rho \theta^{t+1} \tilde{e}^{t} \tilde{q}^{t}$, where $\lambda^{t+1}$ and $\theta^{t+1}$ are the shadow prices of the resource and waste stock, respectively. The optimal finite-time solution must satisfy equations (B2) and (B3) and the following conditions:

$$
\begin{aligned}
& \frac{\partial H}{\partial q^{t}}=\tilde{p}^{t}-c^{\prime}\left(\tilde{q}^{t}\right)-\rho \lambda^{t+1}+\rho \theta^{t+1} \tilde{e}^{t}=0 \\
& \rho \lambda^{t+1}=\lambda^{t} \\
& \rho \theta^{t+1}=\theta^{t}
\end{aligned}
$$

Equations (B2)-(B3) together with (B5)-(B6) characterize the dynamic evolution of the solution. By using (B5)-(B6) and rewriting (B4) we obtain equation (5) in section 4.2. 
Appendix C

Table C1. Simulation results under uncertainty, resource and environmental policy intervention

Production level Target 1 and probability of environmental accident 1/100

\begin{tabular}{|c|c|c|c|c|c|c|c|c|c|c|c|c|c|}
\hline & \multirow{2}{*}{$\begin{array}{l}\text { Low-Cost } \\
\text { No Policy } \\
\text { Instrument }\end{array}$} & \multicolumn{4}{|c|}{ Ad Valorem Tax, $\tau=0.05$} & \multicolumn{4}{|c|}{ Royalty, $\lambda=\$ 1.6 /$ ton of ore } & \multicolumn{4}{|c|}{ Excess Corporate Tax, $\tau=0.14$} \\
\hline & & $\begin{array}{c}\text { Fine } \\
\$ 200 \mathrm{M}\end{array}$ & $\begin{array}{l}\text { Up-Front } \\
\text { Payment } \\
\mathrm{P}=\$ 20 \mathrm{M}\end{array}$ & \begin{tabular}{|c|}
$\begin{array}{c}\text { Surety } \\
\text { Bond } \\
\mathrm{B}=\$ 200 \mathrm{M}\end{array}$ \\
\end{tabular} & $\begin{array}{l}\text { Pigou Tax } \\
\$ 1000 / \text { ton } \\
\text { of effluent }\end{array}$ & $\begin{array}{c}\text { Fine } \\
\$ 200 \mathrm{M}\end{array}$ & $\begin{array}{l}\text { Up-Front } \\
\text { Payment } \\
\mathrm{P}=\$ 20 \mathrm{M}\end{array}$ & $\begin{array}{c}\begin{array}{c}\text { Surety } \\
\text { Bond } \\
\mathrm{B}=\$ 200 \mathrm{M}\end{array} \\
\end{array}$ & $\begin{array}{l}\text { Pigou Tax } \\
\$ 1000 / \text { ton } \\
\text { of effluent }\end{array}$ & $\begin{array}{l}\text { Fine, } \\
\$ 200 \mathrm{M}\end{array}$ & $\begin{array}{l}\text { Up-Front } \\
\text { Payment } \\
\mathrm{P}=\$ 20 \mathrm{M}\end{array}$ & $\begin{array}{c}\text { Surety } \\
\text { Bond } \\
\mathrm{B}=\$ 200 \mathrm{M}\end{array}$ & $\begin{array}{l}\text { Pigou Tax } \\
\$ 1000 / \text { ton } \\
\text { of effluent }\end{array}$ \\
\hline Corporate Taxes $(20 \%)$ & 0 & 194 & 194 & 194 & 194 & 194 & 194 & 194 & 194 & 194 & 194 & 194 & 194 \\
\hline Ad Valorem Taxes & 0 & 138 & 138 & 138 & 138 & 0 & 0 & 0 & 0 & 0 & 0 & 0 & 0 \\
\hline Royalties & 0 & 0 & 0 & 0 & 0 & 135 & 135 & 135 & 135 & 0 & 0 & 0 & 0 \\
\hline Excess Corporate Taxes & 0 & 0 & 0 & 0 & 0 & 0 & 0 & 0 & 0 & 136 & 136 & 136 & 136 \\
\hline Fines & 0 & 12 & 0 & 0 & 0 & 12 & 0 & 0 & 0 & 12 & 0 & 0 & 0 \\
\hline Up-front Payment & 0 & 0 & 20 & 0 & 0 & 0 & 20 & 0 & 0 & 0 & 20 & 0 & 0 \\
\hline Surety Bond & 0 & 0 & 0 & 155 & 0 & 0 & 0 & 155 & 0 & 0 & 0 & 155 & 0 \\
\hline Pigou Taxes & 0 & 0 & 0 & 0 & 198 & 0 & 0 & 0 & 198 & 0 & 0 & 0 & 198 \\
\hline Government Revenue & $\mathbf{0}$ & 343 & 352 & 487 & 530 & 341 & 349 & 485 & 527 & 342 & 350 & 485 & 528 \\
\hline Damages from an accident & 12 & 12 & 12 & 12 & 12 & 12 & 12 & 12 & 12 & 12 & 12 & 12 & 12 \\
\hline Average Net-of-Tax Profits & 1,655 & 933 & 936 & 801 & 520 & 935 & 939 & 804 & 523 & 955 & 958 & 823 & 542 \\
\hline $\mathrm{NPV}>0(\%)$ & 87.8 & 73.3 & 72.9 & 69.7 & 59.5 & 71.6 & 71.8 & 68.4 & 58.1 & 77.0 & 77.4 & 72.4 & 63.5 \\
\hline
\end{tabular}

Notes: The operating costs are low (\$20/ton of ore), corporate tax rate is $20 \%$. The taxes and profits in each row are reported in NPV and measured in millions of US dollars.

Accident occurs with a probability of $258 / 30000=0.86 \%$, or on average 0.26 times in 30 years. 
Net Present Value of the Mine

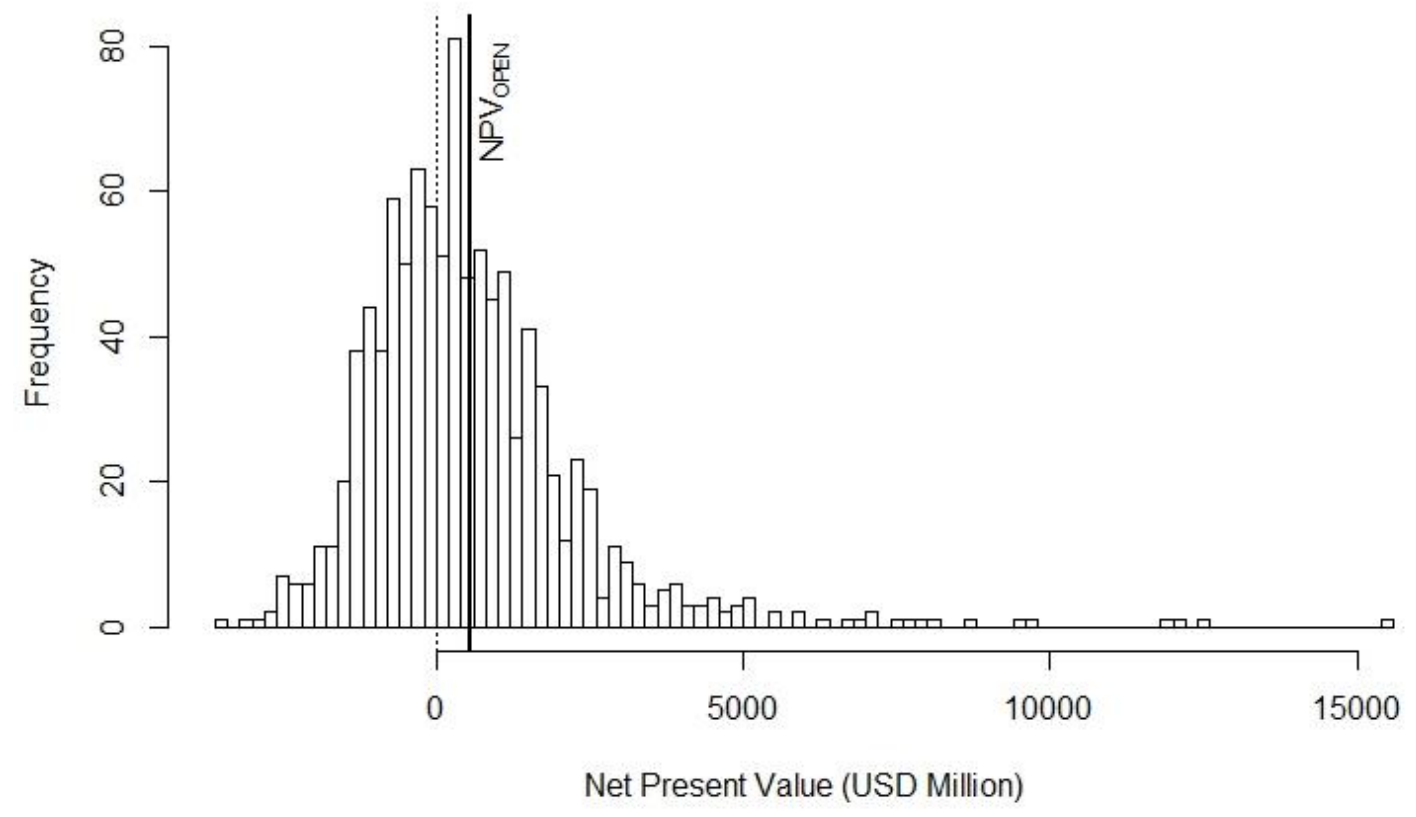

Government Collects, in Net Present Value

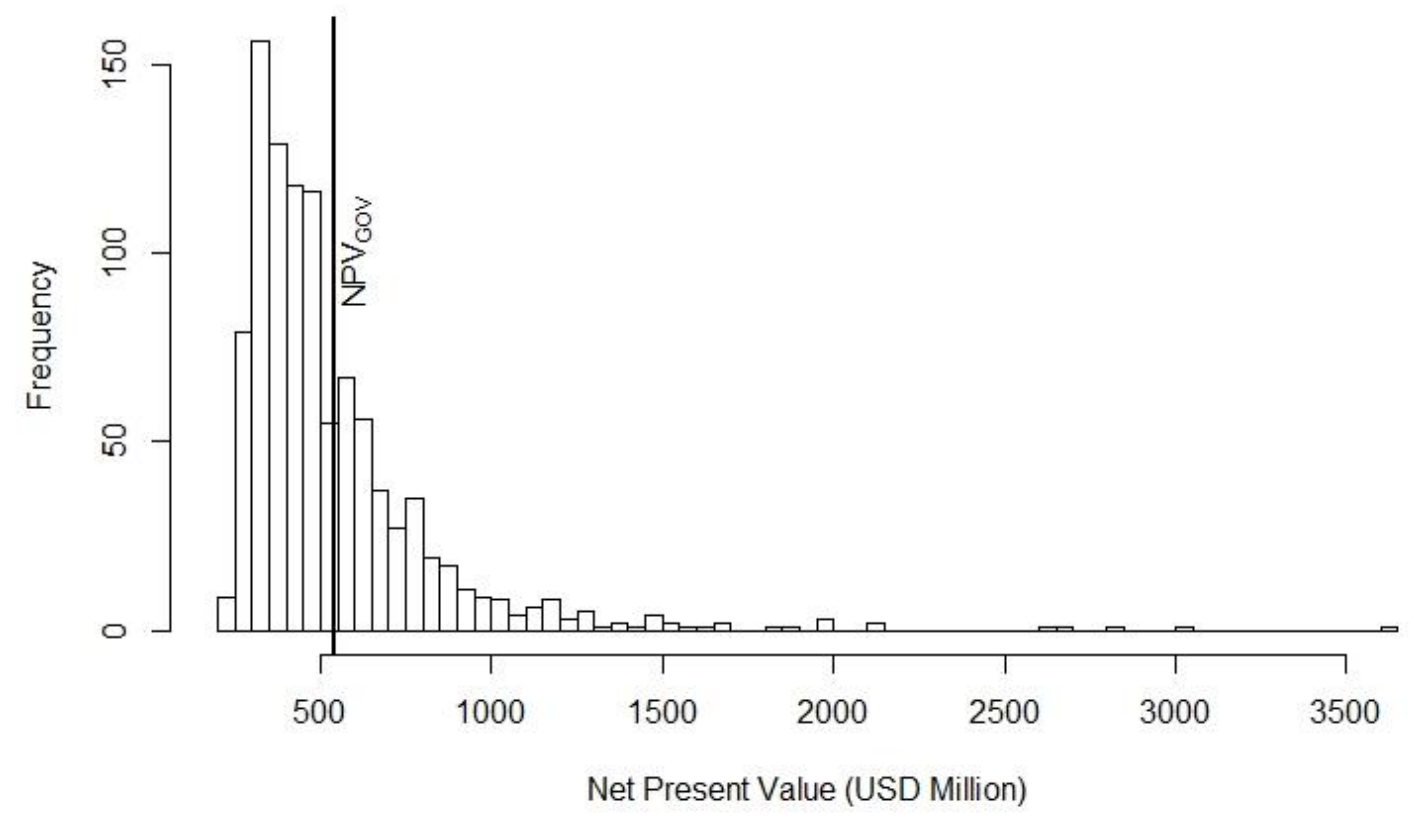

Figure D1. Simulated net present values of firm profits and government revenues with ad valorem tax 5\%, corporate tax 20\% and Pigou tax USD 1,000 per ton of effluent (Production level Target 1) 